\title{
Potential mechanisms for the genesis of Cenozoic domal structures on the NE Atlantic margin: pros, cons and some new ideas
}

\author{
A. G. DORÉ 1 , E. R. LUNDIN ${ }^{2}$, N. J. KUSZNIR ${ }^{3}$ \& C. PASCAL ${ }^{4}$ \\ ${ }^{1}$ StatoilHydro Gulf of Mexico, 2103 City West Boulevard, Suite 800, Houston, Texas 77042, USA \\ (e-mail:agdo@statoilhydro.com) \\ ${ }^{2}$ Statoil Research Centre, Postuttak, 7005 Trondheim, Norway \\ ${ }^{3}$ Department of Earth and Ocean Sciences, University of Liverpool, Liverpool L69 3BX, UK \\ ${ }^{4}$ Geological Survey of Norway (NGU), P.O. Box 3006, N-7002 Trondheim, Norway
}

\begin{abstract}
The mild compressional structures of Cenozoic age on the passive margins bordering Norway, the UK, the Faroes and Ireland have been the subject of much discussion in the literature. Nevertheless, their origin remains enigmatic. Candidate mechanisms must be able to explain the generation of sufficient stress to cause deformation, the episodic nature of the structures and why they developed where they did. We examine these mechanisms and conclude that multiple causes are probable, while favouring body force as potentially the most important agent.

The geometry and setting of the structures are incompatible with gravitational sliding and toethrusting, probably the commonest 'compressive' structuring around the Atlantic margins. A passive mode of origin featuring drape or flank sedimentary loading probably emphasized some of the structures, but cannot be invoked as a primary mechanism. Likewise, reactivation of basement structure probably focused deformation but did not initiate it. Far-field orogenic stress from Alpine orogenic phases and from the West Spitsbergen-Eurekan folding and thrusting is also examined. This mechanism is attractive because of its potential to explain episodicity of the compressional structures. However, difficulties exist with stress transmission pathways from these fold belts, and the passive margin structures developed for much of their existence in the absence of any nearby contemporaneous orogeny. Breakup and plate spreading forces such as divergent asthenosheric flow have potential to explain early post-breakup compressional structuring, for example on the UK-Faroes margin, but are unlikely to account for later (Neogene) deformation.

Ridge push, generally thought to be the dominant body force acting on passive margins, can in some circumstances generate enough stress to cause mild deformation, but appears to have low potential to explain episodicity. It is proposed here that the primary agent generating the body force was development of the Iceland Insular Margin, the significant bathymetric-topographic high around Iceland. Circumstantially, in Miocene times, this development may also have coincided with the acme of the compressional structures. We show that, dependent on the degree of lithosphere-asthenosphere coupling, the Iceland Plateau may have generated enough horizontal stress to deform adjacent margins, and may explain the arcuate distribution of the compressional structures around Iceland.

Assuming transmission of stress through the basement we argue that, through time, the structures will have developed preferentially where the basement is hotter, weaker and therefore more prone to shearing at the relatively low stress levels. This situation is most likely at the stretched and most thermally-blanketed crust under the thickest parts of the young (Cretaceous-Cenozoic) basins. Although several elements of this model remain to be tested, it has the potential to provide a general explanation for passive margin compression at comparatively low stress levels and in the absence of nearby orogeny or gravitational sliding.
\end{abstract}

At the time of plate separation in the NE Atlantic in the early Eocene (53.7 Ma, Chron 24B) the oceanic margins were bounded by a thick sedimentary pile that had accumulated during a succession of extensional episodes lasting some $350 \mathrm{Ma}$ (Doré et al. 1999). The sedimentary pile is up to $17 \mathrm{~km}$ thick (in the Møre Basin) and consists primarily of Cretaceous and Cenozoic sediments. On outer parts of the margin, the basin fill is further increased by thick breakup-related flood basalts of Paleocene-Eocene age.
During and subsequent to breakup, the basins marginal to the NE Atlantic were deformed into a series of domes, generally elongate anticlines with 4-way closure at Cretaceous-Cenozoic level, generally simply inverted without a marked directional asymmetry, but in some instances verging in the direction of a reverse fault system in the core of the fold. The domes are generally assumed to have a compressional element, but at low strain levels representing only a few percent shortening (e.g. Vågnes et al. 1998). They can, however, be 
areally large and this factor, combined with the presence of potential reservoir sandstones in the Cretaceous and Cenozoic successions, makes them interesting targets for petroleum exploration. Members of this structural suite have been identified between Hatton Bank and the Faroe-Shetland
Basin (e.g. Johnson et al. 2005), on the Faroes shelf (e.g. Boldreel \& Andersen 1993) and on the MidNorwegian margin (e.g. Blystad et al. 1995; Doré \& Lundin 1996; Lundin \& Doré 2002). Similar, albeit lesser studied, features have been identified onshore East Greenland (Price et al. 1997) and

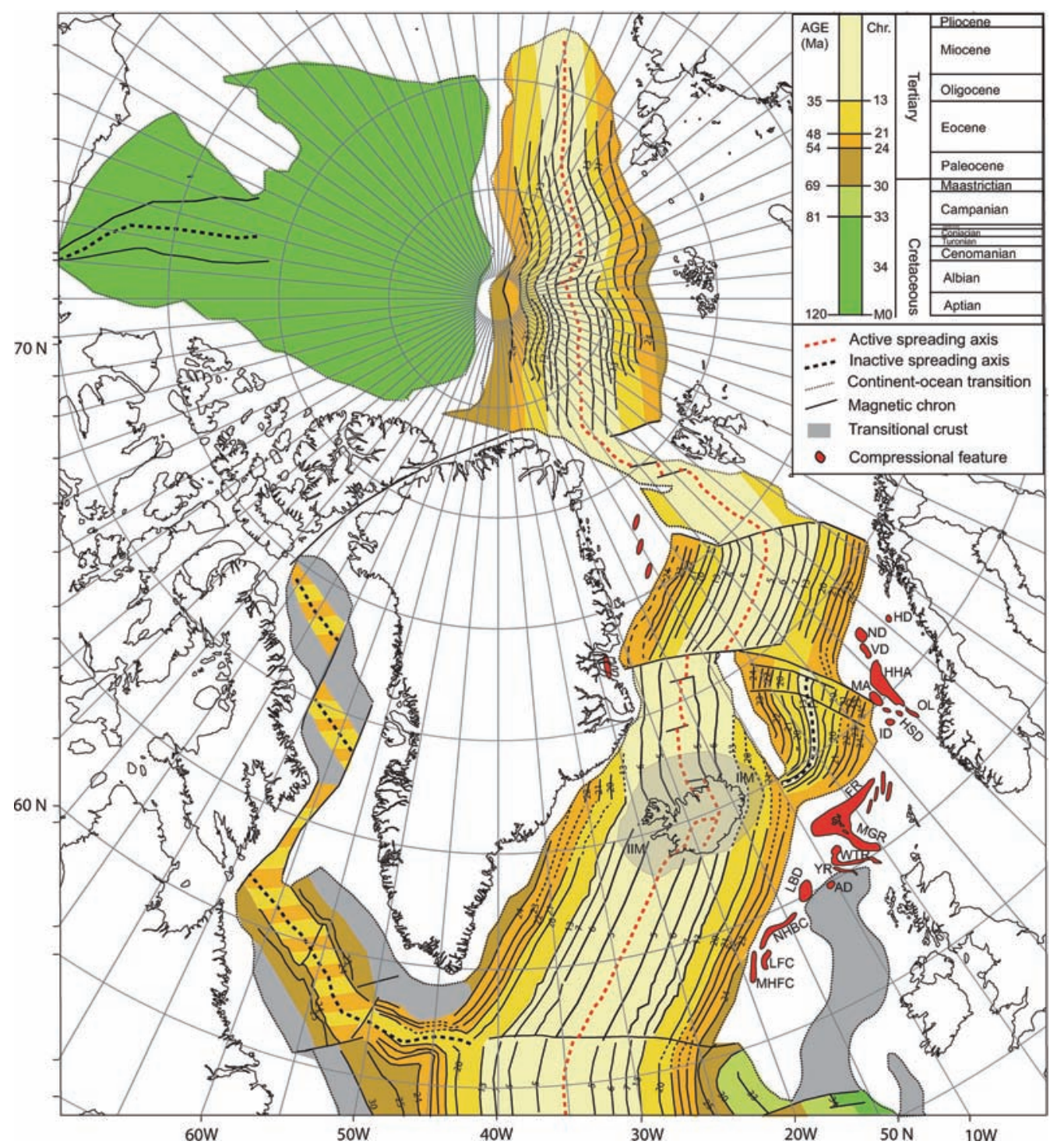

Fig. 1. Super-regional plate tectonic map of the NE Atlantic, Labrador Sea/Baffin Bay, and Arctic Ocean, with inversion features marked in red. Seafloor spreading anomalies marked with respective numbers and colour coded. Abbreviations: AD, Alpin Dome; FR, Fugløy Ridge; HD, Hedda Dome; HHA, Helland Hansen Arch; HSD, Havsule Dome; ID, Isak Dome; IIM, Iceland Insular Margin; LBD, Lousy Bank Dome; LFC, Lyonesse Fold Complex; MA, Modgunn Arch; MGR, Munkagunnar Ridge; MHFC, Mid-Hatton Bank Fold Complex; ND, Naglfar Dome; NHBA, North Hatton Basin Anticline; NHBC, North Hatton Bank Fold Complex; OL, Ormen Lange Dome; VD, Vema Dome; WTR, Wyville Thomson Ridge; YR, Ymir Ridge. Red dashed lines, active spreading axes; Black dashed lines, abandoned spreading axes. Polar stereographic north projection. Modified after Lundin (2002). 
briefly described offshore NE Greenland (Hamann et al. 2005; Tsikalas et al. 2005) (Fig. 1).

We believe that on a very generic level it is important to distinguish between two classes of domes, both of which are evident and lie in close juxtaposition on the Mid-Norwegian shelf (Fig. 2). They are superficially similar in morphology but appear to differ in timing and origin. The first and earlier class is of Late Cretaceous to Paleocene age and is related to breakup magmatism. We term these features 'tectonomagmatic' because the broad domal uplifts appear to be associated with intrusion or the emplacement of remobilized crust or magmatically underplated material at depth. Examples include the Gjallar Ridge, which has been characterized as an incipient core complex (Lundin \& Doré 1997; Doré et al. 1999; Ren et al. 1998; Gernigon et al. 2003), the palaeo-Vema
Dome, in which an early uplift collapsed in Paleocene times and was infilled by sediments prior to the later (Miocene) doming event (Lundin \& Doré 2002), and the Isak Dome (informal name) which had an early phase of doming in latest Cretaceous time and subsequently one in Miocene time. The second and later class of features, which we term 'compressional-compactional' are post-breakup in age (i.e. early Eocene to Recent) and form the main subject of this paper. On the Mid-Norwegian shelf they include the Ormen Lange Dome, Havsule Dome, Modgunn Arch, and Isak Dome at the Vøring-Møre Basin transition. To the north lies the largest of these features, the HellandHansen Arch with a north-south fold axis in the order of $200 \mathrm{~km}$ in length and an amplitude in the order of $1000 \mathrm{~m}$ (Fig. 3) and, farther north still, the Vema, Naglfar, and Hedda (informal name)

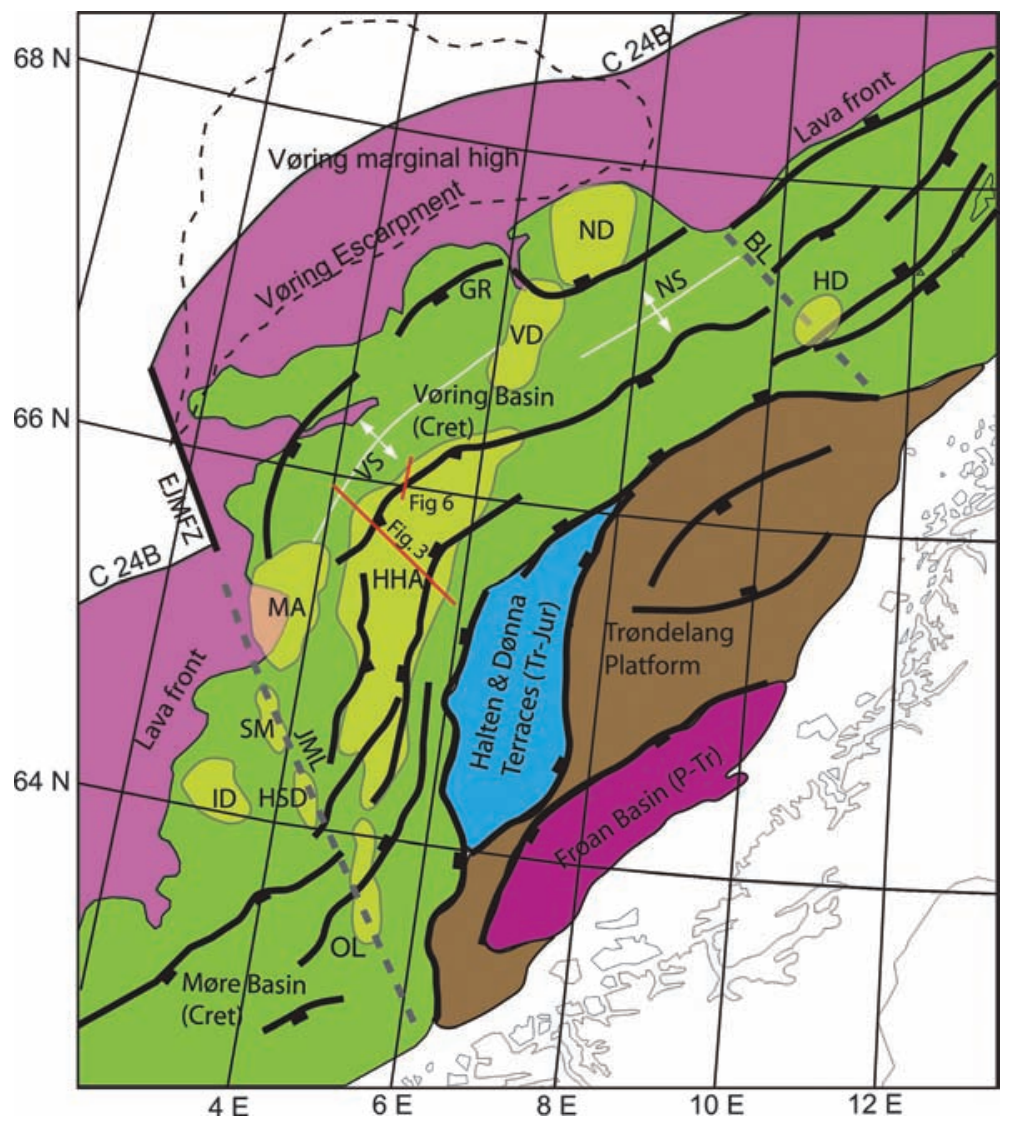

Fig. 2. Simplified structural map of mid-Norway illustrating the inversion features in relationship to main structural provinces and structures. Abbreviations: BL, Bivrost Lineament; EJMFZ, East Jan Mayen Fracture Zone; GR, Gjallar Ridge; HD, Hedda Dome; HHA, Helland Hansen Arch; HSD, Havsule Dome; ID, Isak Dome; JML, Jan Mayen Lineament; MA, Modgunn Arch; ND, Naglfar Dome; NS, Någrind Syncline; OL, Ormen Lange Dome; SM, Souther Modgunn Arch; VD, Vema Dome; VS, Vigrid Syncline. Red lines refer to seismic profiles shown in Figures 3 \& 6. UTM Zone 33 projection. 


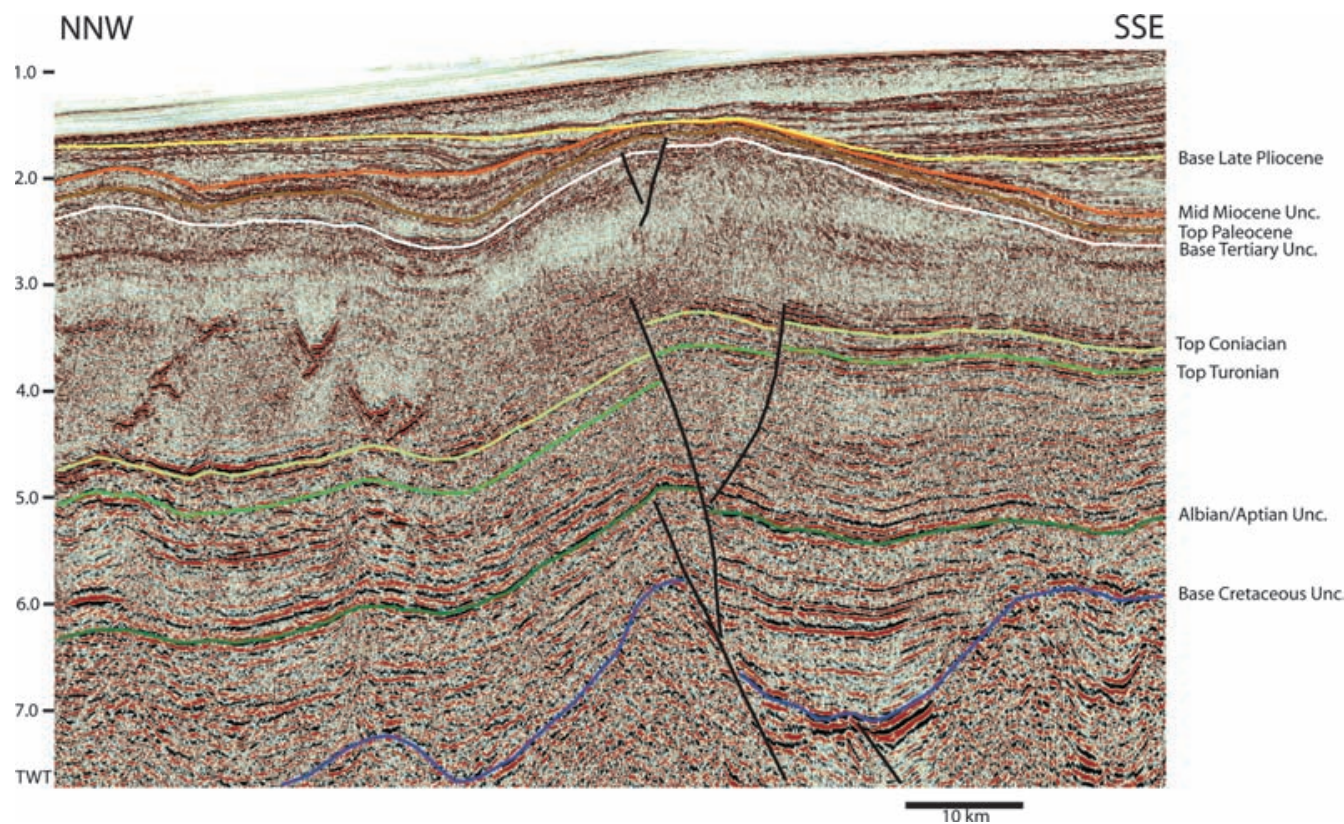

Fig. 3. Seismic profile of southern Helland Hansen Arch, illustrating reverse reactivation of the normal fault bounding the western side of the Rås sub-basin. Line of section shown on Figure 2.

domes (Figs $1 \&$ 2). Structures generally assigned to this suite in the UK and Faroes sector to the south include the Pilot Whale Anticline and Wyville Thompson, Munkegrunnur and Ymir ridges (e.g. Boldreel \& Andersen 1998; Johnson et al. 2005) (Fig. 1).

Numerous potential mechanisms have been suggested for the formation of the post-breakup domal structures. These include deformation of the sedimentary pile by far-field orogenic (principally Alpine) forces (e.g. Brekke 2000; Vågnes et al. 1998), reactivation of basement lineaments under spreading forces and particularly during plate reorganization (Doré \& Lundin 1996), topographic body forces such as ridge push (e.g. Doré \& Lundin 1996; Boldreel \& Andersen 1998), mantle drag (e.g. Mosar et al. 2002) emphasized by pulses in flux of a supposed Iceland plume (e.g. Lundin \& Doré 2002), and sedimentary flank loading and differential compaction (e.g. Stuevold et al. 1992; Kjeldstad et al. 2003). The main purpose of this paper is to review these and other potential mechanisms and assess their relative merits.

Timing (Fig. 4) is probably the most critical factor in distinguishing between potential mechanisms, because it allows us to equate phases of structural development with external factors such as plate boundary forces. For this purpose, key events during the development of the NE Atlantic are described with reference to a series of four plate reconstructions (Fig. $5 \mathrm{a}-\mathrm{d}$ ).

Rotation poles used for moving Greenland with respect to a fixed Eurasia, after Gaina et al. (2002) are:

\begin{tabular}{lccc}
\hline $\begin{array}{l}\text { Time } \\
(\mathrm{Ma})\end{array}$ & $\begin{array}{c}\text { Latitude } \\
\left({ }^{\circ} \mathrm{N}\right)\end{array}$ & $\begin{array}{c}\text { Longitude } \\
\left({ }^{\circ} \mathrm{W}\right)\end{array}$ & $\begin{array}{c}\text { Rotation } \\
\text { angle }\left({ }^{\circ}\right)\end{array}$ \\
\hline 53 & 52.28 & 123.2 & 11.2 \\
33 & 68.22 & 131.53 & 7.64 \\
18 & 68.58 & 132.58 & 4.5 \\
\hline
\end{tabular}

\section{Early Eocene (c. 53 Ma) (Fig. 5a)}

An immediate precursor of breakup in the NE Atlantic was uplift and subaerial erosion along the line of incipient separation, together with voluminous basaltic magmatism (e.g. White et al. 1987). Plate reconstructions suggest that plate separation in the Labrador Sea and Baffin Bay occurred approximately in Campanian time (c. $82 \mathrm{Ma}$ ), close to the time proposed by Srivastava \& Roest (1999) , although the initial phase of plate separation was probably characterized by mantle exhumation (Louden et al. 1996). In late Mastrichtian time (c. $68 \mathrm{Ma}$ ) classic seafloor spreading with formation of basaltic oceanic crust began. This 


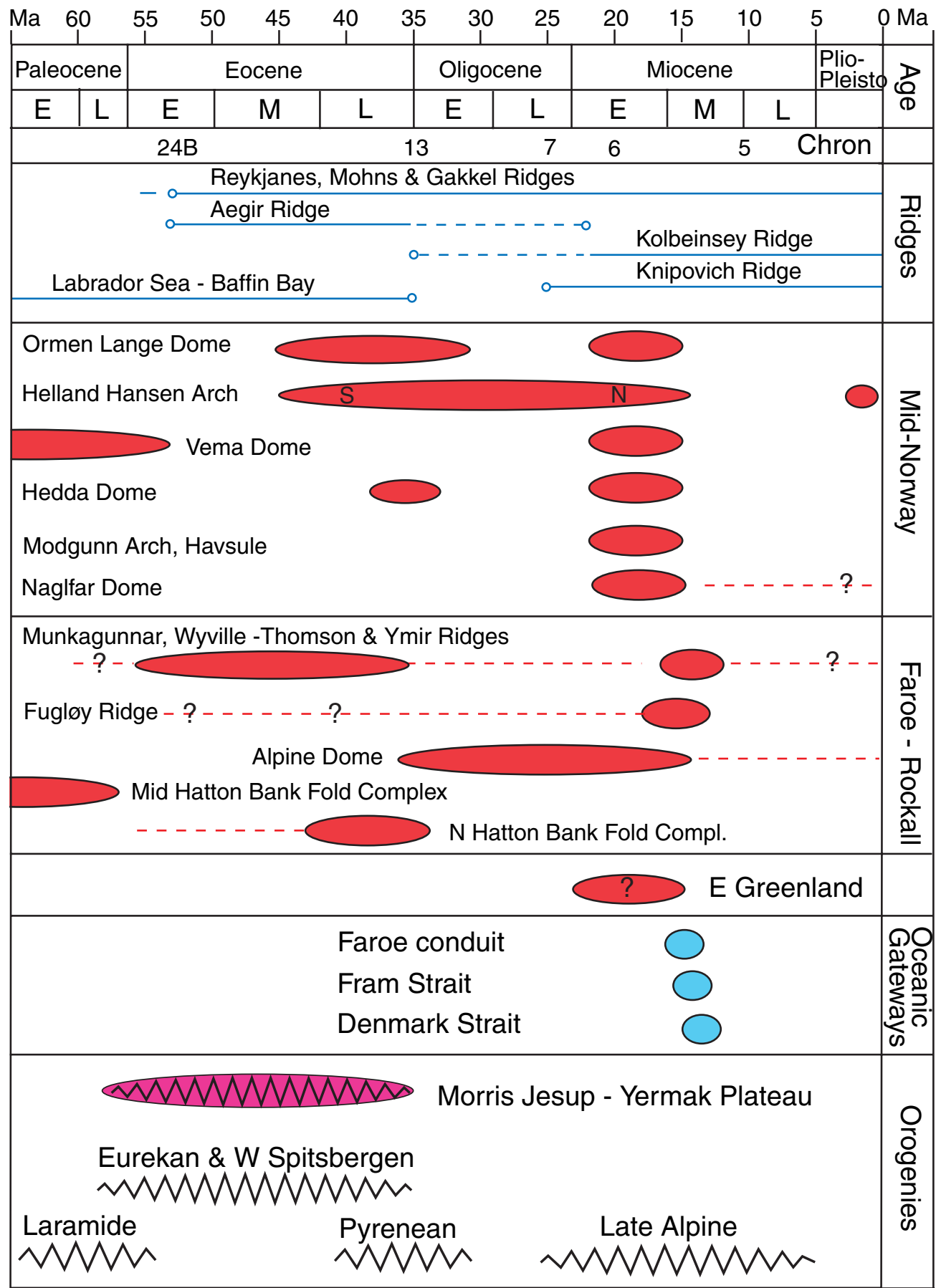

Fig. 4. Chronological diagram illustrating the approximate timing of inversion and its relationship to seafloor spreading, orogeny and oceanographic events. Modified after Lundin \& Doré, 2002; Johnson et al. 2005; Smallwood 2004; Stoker et al., 2005a, b. 

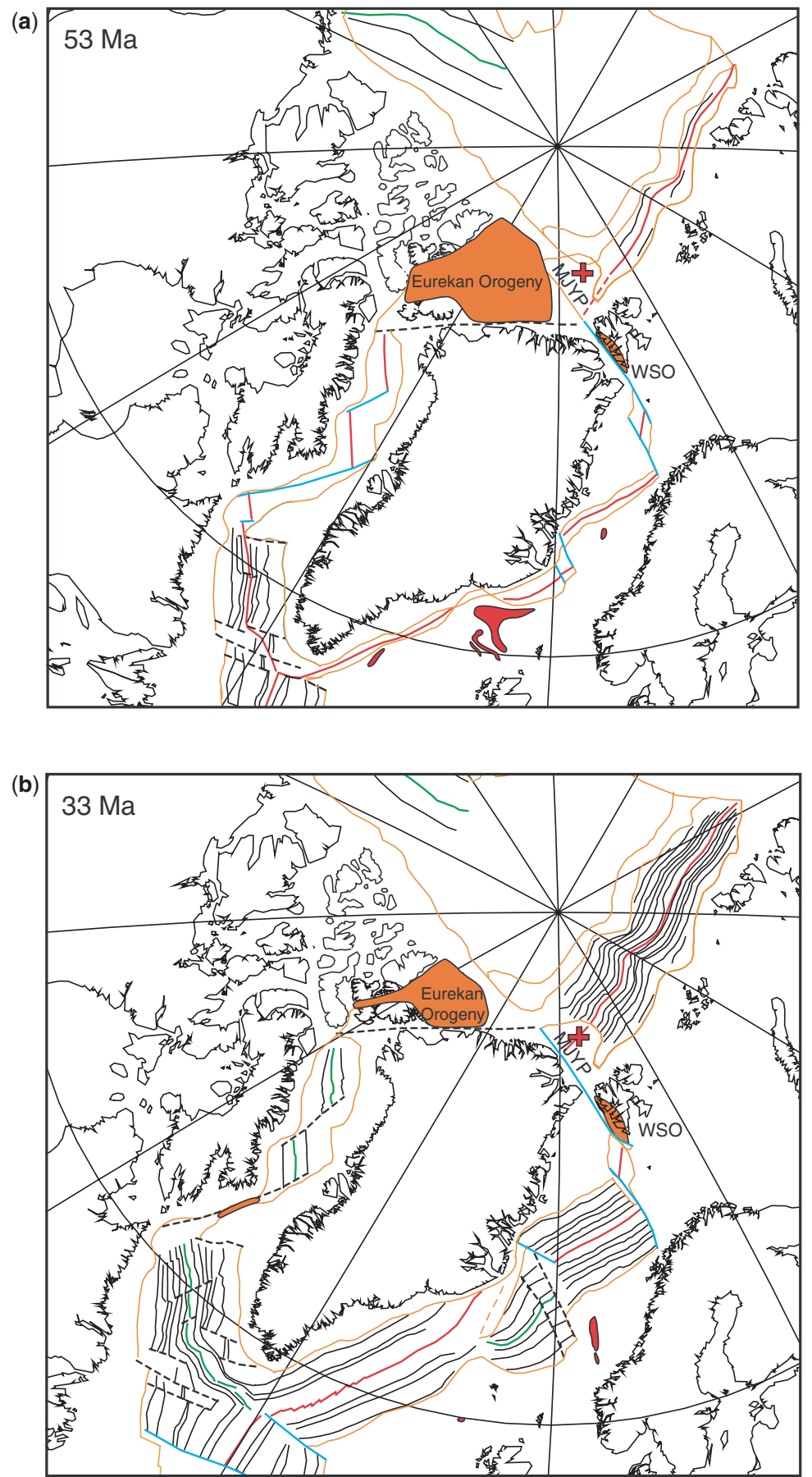

Fig. 5. A series of plate reconstructions for the NE Atlantic and Arctic to illustrate key events relating to development of the compressional structures (red blobs). Continent-ocean boundaries or transitions (orange lines), fracture zones (blue, active, black dashed, inactive), spreading axes (red, active, green, inactive) and isochrones (black). Passive margin compressional features undergoing development at the time of the reconstruction are shown in bright red. Orogens or areas of significant compression are marked with orange. Isochrons in the Eurasia Basin are mainly after Gaina et al. (2006), in the Labrador Sea after Oakey (2005), and in the NE modified after Lundin (2002) (further references therein) and Gaina et al. (2006). Continent-ocean boundaries in the Fram Strait are after Engen et al. (2008). Software used for 
(c)

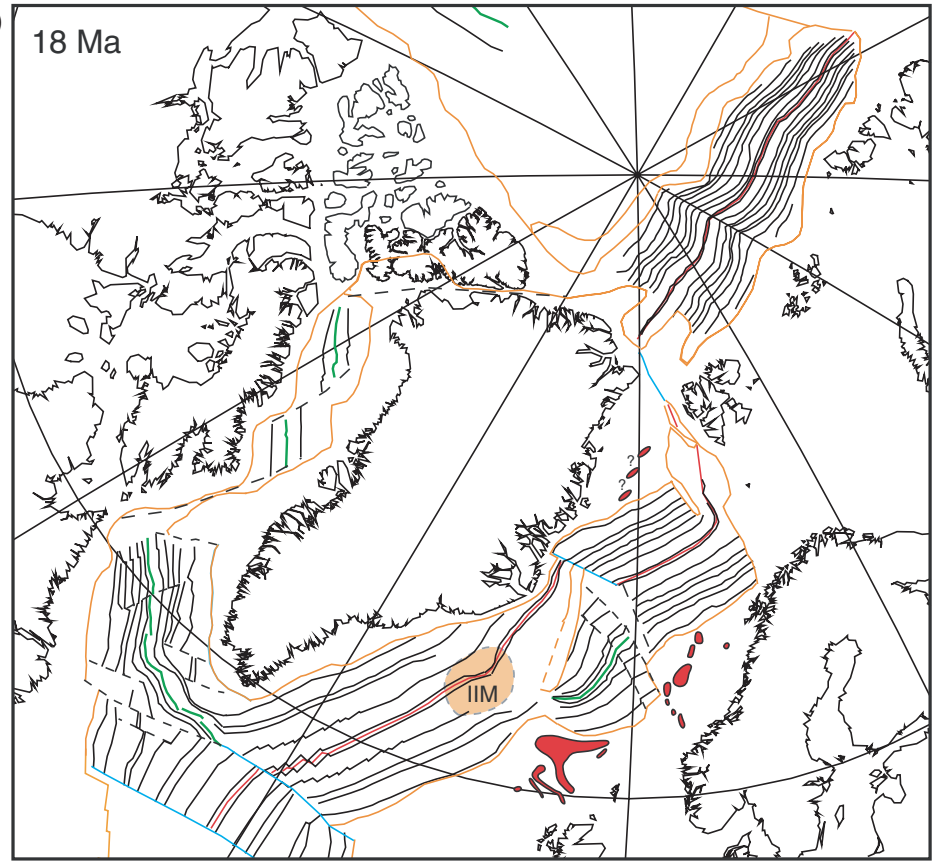

(d)

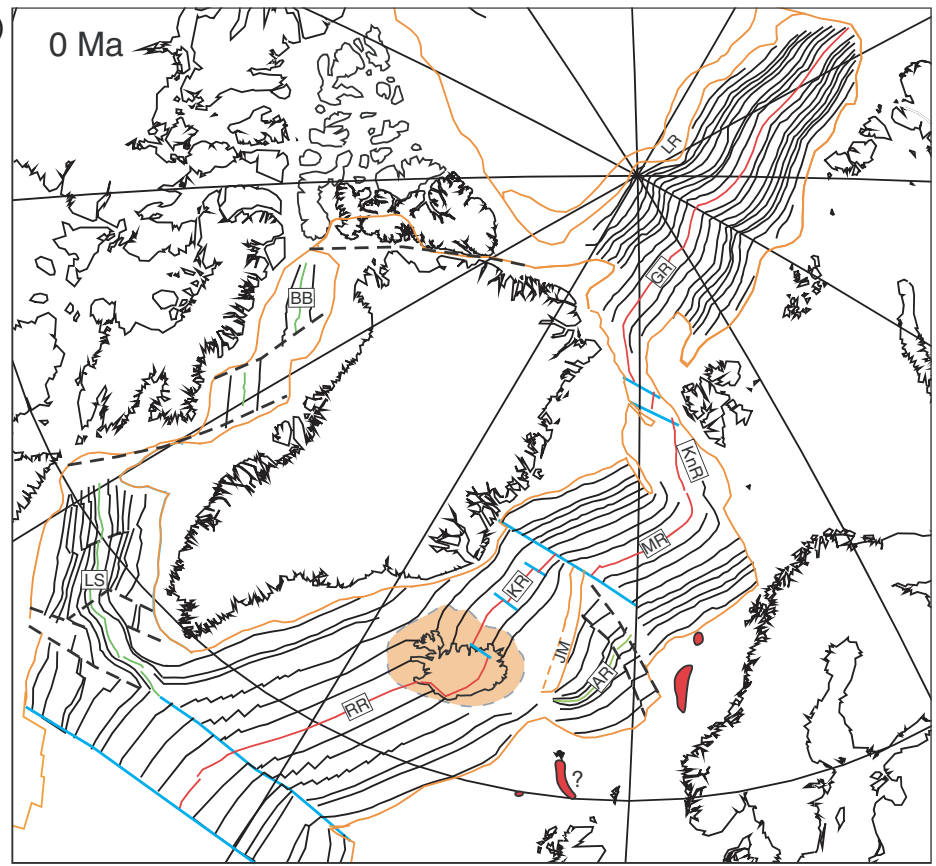

Fig. 5. (Continued) the reconstructions is SPlates (Torsvik et al. 2006). (a) Plate reconstruction to Chron 24 b, 53 Ma. WSO, West Spitsbergen orogenic belt. The plus sign and MJYP represents the Morris Jesup Rise and Yermak Plateau, areas of anomalously high ocean floor which, highly conjecturally, may represent extensions of the orogenic belt.

(b) Plate reconstruction to Chron 13, 33 Ma. (c) Plate reconstruction to Chron 5, 18 Ma. IIM, Iceland Insular Margin. (d) Plates at present, 0 Ma. AR, Aegir Ridge; BB, Baffin Bay; GR, Gakkel Ridge; JM, Jan Mayen microcontinent; KR, Kolbeinsey Ridge; KnR, Knipovitch Ridge; LR, Lomonosov Ridge; LS, Labrador Sea; MR, Mohns Ridge; RR, Reykjanes Ridge. 
estimate is somewhat earlier than that proposed by Chalmers \& Pulvertaft (2001) (Chron 27, $61 \mathrm{Ma}$ ). Upon opening of the NE Atlantic in early Eocene $(53.7 \mathrm{Ma})$, the simultaneous spreading in the two arms of the North Atlantic resulted in Greenland being driven northward relative to the Barents Sea and Canadian Arctic margins, with the development of a transpressional shear margins at the BarentsGreenland boundary, whereas near perpendicular convergence at the North America-Greenland boundary in Nares Strait formed the Eurekan orogenic belt. Immediately following breakup much of the anomalously elevated separation line collapsed and was inundated, but topographically positive areas were maintained along the shear margins and in the orogen to the north. The crustal nature (oceanic versus continental) of the Yermak Plateau and Morris-Yesup Rise at the termination of the Nansen-Gakkel Ridge against northern Greenland is still not resolved. However, these anomalously elevated areas may concievably be elements of the Eurekan and West Spitsbergen foldbelt.

Offshore Mid-Norway, initial growth of compressive structures such as the Ormen Lange Dome and Helland-Hansen Arch began in the middle Eocene (Lundin \& Doré 2002) while farther southwest in the Faroes-Rockall area some authors claim compressional deformation may have begun at the time of breakup, i.e as early as late Paleocene-early Eocene (e.g. Boldreel \& Andersen 1998).

\section{Early Oligocene (c. 33 Ma) (Fig. 5b)}

At the onset of Oligocene time, at Chron 13, drift between Greenland and Norway switched from a NW-SE to a more east-west vector, resulting in a radical reconfiguration of the North Atlantic spreading geometries (e.g. Faleide et al. 1993). The reason for the change of motion is unclear, but in terms of plate-wide kinematics, it may have been related to the contemporaneous Pyrenean phase of Tethyan closure (Fig. 4), which radically affected the southwestern margin of the Eurasian Plate.

A spreading link had begun to develop between Jan Mayen and East Greenland, via the Kolbeinsey Ridge to the Mohns Ridge. Linkage was achieved between the northward propagating Kolbeinsey Ridge and the Mohns Ridge at Chron 13. Activity on the shear margin between the Barents SeaSpitsbergen and Greenland ceased and gave way to rifting and eventually to passive drift, with the gradual linkage of the Nansen-Gakkel Ridge in the Nansen Basin with the Mohns Ridge via the nascent Knipovich Ridge. At the same time, all the compressional belts around Greenland, in the Davis Strait, on Spitsbergen along the SW Barents
Sea margin, and the Eurekan Orogeny in the Canadian Arctic ceased, as did the development of the anomalously high ocean-floor between North Greenland and Spitsbergen comprising the Yermak Plateau and Morris-Jesup Rise. Spreading in the Labrador Sea and Baffin Bay is generally accepted to have ceased at Chron 13 times, with the result that Greenland became effectively part of the North American Plate (Kristoffersen \& Talwani 1977).

Moderate landmass uplift took place at this time on the Norwegian mainland and in East Greenland, with continuing minor evolution of compressional structures in the Norwegian Sea (Lundin \& Doré 2002) and Faroes-Rockall area (Johnson et al. 2005).

\section{Middle Miocene (c. 18 Ma) (Fig. 5c)}

The middle Miocene saw an important phase of development of the compressional features, both in the Norwegian Sea (Lundin \& Doré 2002) and Faroes-Rockall area (Johnson et al. 2005). This interval was not marked locally by significant changes in spreading direction, but nevertheless included some important events in the development of the NE Atlantic.

To the south, in the Betic Chain (southern Spain), the main phase of orogenic compression occurred at this time (Berástegui et al. 1998), also roughly contemporaneous with the Late Alpine Tethyan closure phase, which lasted from Miocene to early Pliocene (e.g. Ziegler 1988).

The Wyville-Thomson Ridge complex (eastern part of the Greenland-Faroe Ridge) became breached at this time, possibly due to compressional buckling, resulting in development of the Faroes Conduit (Stoker et al. 2005a, b). Breaching this major bathymetric barrier permitted oceanic circulation between the Norwegian-Greenland Sea and the northern Atlantic, and led to deposition of major contourite drift deposits (Fig. 6).

Rifting that had started in earliest Oligocene times in the Fram Strait and along the SW Barents Sea margin gave way to seafloor spreading in middle Miocene time (c. $18 \mathrm{Ma}$ according to our in-house work, and $16 \mathrm{Ma}$ according to Engen et al. 2008). Thereby, a continuous Atlantic spreading ridge was established between the southern tip of the South Atlantic and the tip of the Gakkel Ridge in the Laptev Sea of the Arctic, spanning approximately half the Earth's circumference. It is intriguing to speculate whether this fundamental link-up resulted in any circulation changes in the underlying mantle, with potential implications for uplift and body force, as suggested in a later (late Pliocene) context by Stoker et al. (2005a). Certainly, uplift of landmasses can, locally, be timed 

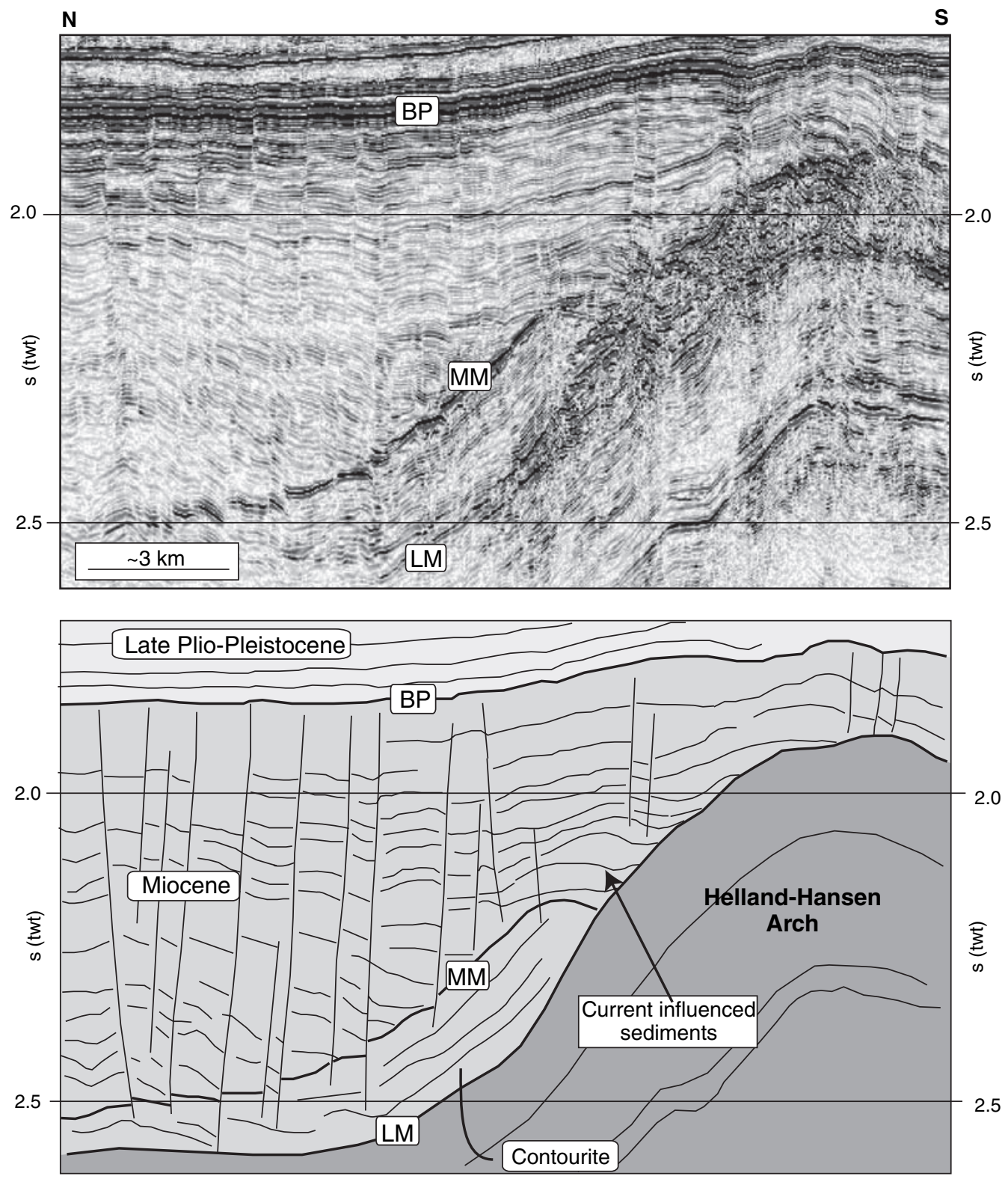

Fig. 6. Seismic profile of northern Helland Hansen Arch, illustrating the mid-Miocene growth phase. Two phases of Miocene contourite deposition along the western flank of the arch have been interpreted to reflect a significant mid-Miocene change in the bottom-current circulation system in response to the compressive episode (Hjelstuen $\mathrm{et} \mathrm{al}$. 2004; Stoker et al. 2005a). BP, Base Late Pliocene; MM, Middle Miocene unconformity; LM, Top Lower Miocene. After Hjelstuen et al. 2004. Line of section shown on Figure 2.

to the middle Miocene. Southern Norway was uplifted and sediments were shed southwards toward the Central Graben and Denmark (e.g. Jordt et al. 2000; Rasmussen 2004). The northern North Sea was subject to uplift, subaerial erosion, and associated valley incision into Oligocene strata during the Miocene (Jordt et al. 2000 and references therein) and seismic mapping has led to proposed incised valleys draining NW into the Møre Basin (Martinsen et al. 1999). Major eastward 
shelf progradation off NE Greenland has been proposed to be of Miocene age based on seismic interpretation (Hamann et al. 2005), and must reflect a major uplift event of the NE Greenland margin regardless of the precise age. Notably, these seismically mapped sequences remain uncalibrated by drilling and their significance cannot be appreciated fully until better time constraints have been obtained.

The Iceland Insular Margin is an enigmatic feature in the NE Atlantic, whose origin remains poorly understood. The $c$. $500 \mathrm{~km}$ wide plateau may have originated from lower crustal flow above the presumed Iceland plume (Jones \& Maclennan 2005). Another possibility is that the plateau represents a major phase of subaerial flood basalt flow, over pre-existing oceanic crust. Lacking firm evidence from age dated cores, the age of the Iceland Insular Margin is only loosely confined to the Miocene (Ellen, 2002). However, it is remarkable that the dominant phase of $\mathrm{NE}$ Atlantic compression occurred in middle Miocene time and that these compressional features form an arc centred on Iceland (e.g. Figs 1 \& 8). A causal relationship is therefore possible, and is discussed in detail later.

\section{Late Pliocene to Recent (illustrated by reconstruction at $0 \mathrm{Ma}$ ) (Fig. $5 d$ )}

The Late Pliocene marked a significant environmental change in the northern hemisphere, reflecting the interaction between climate deterioration and a pre-existing landscape. Major prograding wedges forming mouth trough fans are especially well developed off the Mid-Norwegian, the SW and north Barents Sea margins, and to a smaller extent off central East Greenland (Vorren \& Laberg 1997). Smaller prograding wedges exist as far south as offshore northern Ireland (Stoker et al. 2005a).

Stoker et al. (2005a) have argued convincingly that early Pliocene tectonic uplift predated the late Pliocene glaciation. Recent redating of the Molo Formation offshore mid-Norway (Eidvin et al. 2007), places this prominent and widespread fluvial delta in the earliest Pliocene. The delta marks a significant basinward shift of the Norwegian palaeocoastline along the formation's mapped extent from Lofoten to mid-Norway (e.g. Henriksen \& Weimer 1996). These fluvial deposits are geometrically and compositionally different from the volumetrically much larger overlying late Pliocene and younger glaciomarine prograding wedges of the Naust Formation. The timing and environmental change between the Molo and Naust formations agree with Stoker et al.'s (2005a) suggestion of an early Pliocene tectonic uplift predating the climatic change and associated erosional and isostatic uplift.

It has been proposed that an early Pliocene plate reorganization caused the development of the Panama Isthmus (Cloetingh et al. 1990), ending communication between the Atlantic and Pacific Oceans, and instead forcing the equatorial Atlantic waters to circulate northward (Lear et al. 2003). Such a development would support the proposal that already existing topographic highs acted as nucleation points upon which the ice caps started to grow (Eyles 1996).

\section{Potential mechanisms for development of the compressional structures}

\section{Gravity loading, spreading and sliding}

The outer parts of many passive margins are characterized by deep-water foldbelts, commonly kinematically coupled to extension near the shelf break. Most of these foldbelts are gravity induced. They did not form by tectonic shortening but were essentially a result of rapid sediment input into the passive margin basins. They are by far the most common of the compressional features around the Atlantic, occurring for example offshore West Africa, off Brazil and in the USA Gulf of Mexico. The foldbelts generally formed as a result of gravitational gliding on a dipping low-friction substrate or by gravitational spreading by differential loading of sedimentary systems. Coupling between the extensional and compressional regimes is particularly efficient where a laterally continuous weak layer can be utilized as a decollement. When exceptionally weak layers are present, such as salt, gravity gliding of the overburden initiates on very low-angle dip slopes (e.g. Vendeville \& Jackson 1992). Passive margins obtain dip through basinward increasing thermal subsidence. Hence, gravity gliding and associated deep-water foldbelts are common along some passive margin regions, particularly where a widespread weak postrift layer is present. The West African and Brazilian Aptian salt basins are such examples.

The deep-water foldbelts readily form where the low-friction substrate terminates basinward, such as against the outer high of the West African and Brazilian margins, where the salt terminates laterally (e.g. Cramez \& Jackson 2000; Mohriak et al. 1998, 2002). Lacking a basinward regional dip, a sedimentary succession above a mechanically weak layer can still be induced to extend by asymmetric loading, such as from a prograding shelf. Such deformation is termed gravity spreading (Vendeville \& Jackson 1992) and can also be 
coupled with foldbelts. Large deltas generate such asymmetric loading and commonly are associated with deep-water foldbelts (e.g. McClay et al. 1998); the Niger delta is an example. In these settings, coupling between extension near the shelf break and the deep-water foldbelt may occur via overpressured shales, or possibly via source rocks going through the window of maturation.

However, evidence of this kind of linkage is missing in the NE Atlantic setting. Although detachments along locally developed Triassic halites have been proposed for the Halten Terrace (Withjack et al. 1989) these developments appear to be local, without the potential to form a universal detachment surface throughout the margin. There is no known seismic evidence to suggest that the Cenozoic domes detach at depth. The compressional structures tend to be basin-centred, not at the seaward edge of the margin as is the case for many of the southern Atlantic gravity-induced foldbelts. Finally, the hinterland loading - detachment foldbelt assemblage is not observed in the area, although as we shall see below, sedimentary loading enhanced the flanks of some structures. As also shown earlier, there is evidence of hinterland uplift and associated sedimentary input to the passive margin basins in the midMiocene (Stoker et al. 2005b; Davies et al. 2004). However, in the main areas where compressional structures are observed (Norwegian Sea and Faroes-Rockall) they do not seem to be associated with contemporaneous mid-Miocene progradation. The one potential candidate for such a progradation, the Molo Formation off mid-Norway (Løseth \& Henriksen 2005) has recently been redated as early Pliocene (Eidvin et al. 2007).

\section{Flank enhancement by sedimentary loading}

The major Helland Hansen Arch off mid-Norway has been proposed to relate to asymmetric loading from a major prograding Plio-Pleistocene glaciomarine sequence, in combination with asymmetric thermal subsidence (e.g. Stuevold et al. 1992; Kjeldstad et al. 2003). This therefore appears to be a mechanism requiring no tectonic shortening at all. Although we recognize the importance of late asymmetric sedimentary loading to forming the east flank of the Helland Hansen Arch (Lundin \& Doré 2002) it is less clear that asymmetric thermal subsidence has generated the western flank of the compressional feature. 3D backstripping and thermal subsidence modelling revealed that the Helland Hansen Arch cannot be completely removed when the asymmetric eastern load is stripped off and when a western asymmetric thermal effect is applied (Roberts et al. 2002). The presence of a mid-Miocene unconformity over the top of the arch (Brekke 2000) is strong evidence that the feature did not initiate only from lateral loading by the Plio-Pleistocene wedge of sediments. Certainly, Plio-Pleistocene loading cannot be a universal dome-forming mechanism in the NE Atlantic since many domes exist beyond the influence of such loads (Stoker et al. $2005 a$ ). It is probably more correct to view the PlioPleistocene progradation as a mechanism sustaining or enhancing pre-existing compressional features rather than one forming them.

More probably, all or most of the domes may have been enhanced by sedimentation and differential compaction on the flanks. Recent work by Gómez \& Vergés (2005) using sequential backstripping has led them to propose a tectonic contribution to the Helland Hansen Arch of as little as $27 \%$ of the total amplitude, with an equivalent value of $37 \%$ for the Vema Dome. The rest of the amplitude in both cases is interpreted to result from loading and differential compaction of the structures' flanks. Should this prove to be the case, the tectonic strain levels required to create the passive margin domes (i.e. crustal shortening) may be even lower than previously supposed - a fraction of a percent according to Gómez \& Vergés (2005).

\section{Transfer of orogenic stress}

From latest Paleocene to the end of the Eocene, a shear margin existed along the Barents Sea western margin, relaying spreading between the Norwegian Sea and Eurasian Basin, while orogeny took place in Spitsbergen and the Canadian Arctic islands due to the northerly movement and impact of Greenland on North American-Arctic lithosphere (see earlier sections and Lundin \& Doré 2005) (Figs 5a, b). Restraining and releasing bends along the shear margin created transpressive (Hornsund Fault Zone) and transtensional (Sørvestnaget Basin) segments (e.g. Faleide et al. 1993; Steel et al. 1985). The West Spitsbergen Orogeny has been attributed to convergent dextral slip along the shear margin, although the direction of structural transport appears to have been from west to east, orthogonal to the margin (Faleide et al. 1988). In the Canadian Arctic (Eurekan) orogen thrusting was to the SE, almost perfectly coincident with the convergence vector between Greenland and North America (Oakey 1994, 2005).

The Eurekan and West Spitsbergen foldbelts formed from northward translation of Greenland in Eocene time (between Chrons 24 and 13). Collision with the North American and Eurasian 
plates ended in earliest Oligocene (Chron 13) when Eurasia moved obliquely away. Plate reconstructions back to Chron 13 reveal that the Yermak Plateau (NW of Svalbard) and the Morris Jesup Plateau north of Greenland formed a single feature prior to Chron 13 (Fig. 5b). This common plateau, here called the Morris Jesup-Yermak Plateau (MJYP) was located between the Eurekan and West Spitsbergen orogens. Based simply on the location of the MJYP, it is tempting to include it as part of a more widespread region of compression north of Greenland (e.g. Brozena et al. 2003). However, the MJYP remains somewhat enigmatic because it is not proven whether the plateau consists of continental crust, oceanic crust or a combination of the two. For alternative interpretations see Feden et al. (1979) and Ritzmann \& Jokat (2003).

This occurrence of orogeny, transpression and transtension on a section of continuous shelf is a factor frequently overlooked in the search for candidate mechanisms for the NE Atlantic inversion structures. In terms of timing, the middle Eocene and early Oligocene initiation of structures such as Ormen Lange and Helland Hansen on the MidNorwegian shelf began during this activity (Lundin \& Doré 2002), while some structuring farther south in the Faroes-Rockall area essentially began at breakup time (Johnson et al. 2005). It is therefore tempting to envisage a regime of distributed compression along the NE Atlantic margin in Eocene times associated with plate interaction between Greenland and North America. It is similarly attractive to postulate a link between the NE Greenland shelf structures (Hamann et al. 2005) and the adjacent Barents shear margin. Problems with this concept are: (1) stresses would need to have been propagated between the orogen and MidNorwegian shelf via a developing ocean basin, or south of the southern termination of the Senja Fracture Zone where little shear should have been taking place (Fig. 5a, b); (2) logically, such propagation along the NE Atlantic shelf should have involved strike-slip zones parallel to the basin axes; no evidence has been brought forward for such activity; and (3) propagation of such stress as far south as Rockall is unlikely.

Transmission of stress from the Alpine orogenessentially representing Tethyan closure and the collision of Africa and Eurasia-has commonly been cited as a likely cause of the compressive deformation on the NE Atlantic shelves, e.g. for the Rockall Trough (Roberts 1989), and for midNorway (Vågnes et al. 1998 and most notably Brekke 2000). Transmission of stress away from collisional fronts for distances up to $1300 \mathrm{~km}$ has been documented for a wide range of orogenic forelands (Ziegler 1988). Orientations of present-day maximum compressive stress from such sources as earthquake focal plane mechanisms and borehole break-outs are NW-SE for much of central and northern Europe, and for the adjacent Atlantic margin (see Fig. 7, an extract from the World Stress Map: Reinecker et al. 2005). This direction is consistent with the direction of closure between Eurasia and Africa. However the maximum compressive stress orientation is almost normal to the NE Atlantic spreading ridges and parallel to the direction of spreading. Hence, it is not possible to attribute the present day stress regime on the NE Atlantic margin conclusively to either Eurasia-Africa convergence or to NE Atlantic ridge push.

The Alpine orogeny began in the Early Cretaceous (Austrian Phase). Cenozoic movements were extremely complex, but three phases of more intense tectonic activity are generally recognized. They comprise the Early Alpine ('Laramide') of late Paleocene age, the Main Alpine ('Pyrenean') approximately straddling the Eocene-Oligocene boundary and the Late Alpine (Miocene-Pliocene starting about $20 \mathrm{Ma}$ ) (Fig. 4). See Ziegler (1988) for the most complete description of this activity as related to associated foreland deformation.

It is possible to equate these phases, in a broad sense, with growth of the domes. Brekke (2000) attributes particular importance to the Main Alpine (Eocene-Oligocene) events, although precise dating appears to place this episode between mid-Eocene inception and main Miocene growth of the mid-Norwegian domes. The Late Alpine orogeny appears to correspond roughly in time with the latter growth phase, and is a plausible causative factor (Fig. 4). Our main issue with this initially attractive hypothesis relates to the distribution of foreland deformation in central Europe. The Alpine phases, although varying in time, space and intensity, caused inversion in the basins of central Europe and propagated northwestwards into the southern North Sea to invert depocentres such as the Broad Fourteens, Sole Pit and West Netherlands basins (Ziegler 1988). This deformation is observed in the south Central Graben and, west of Britain, the Celtic Sea basins, but no further north. The northern North Sea and Møre Basin are essentially devoid of compressive deformation (Pascal \& Gabrielsen 2001). It is thus difficult to understand why such activity should pick up again in, say, the Faroe-Shetland Basin, and even more difficult to envisage in the Vøring Basin, where the Baltic Shield separates the area from the Alpine orogen. Finally, compressive domes identified in East Greenland (Price et al. 1997) and on the NE Greenland shelf (Hamann et al. 2005) cannot be attributed to direct propagation of Alpine stress since these areas were decoupled 


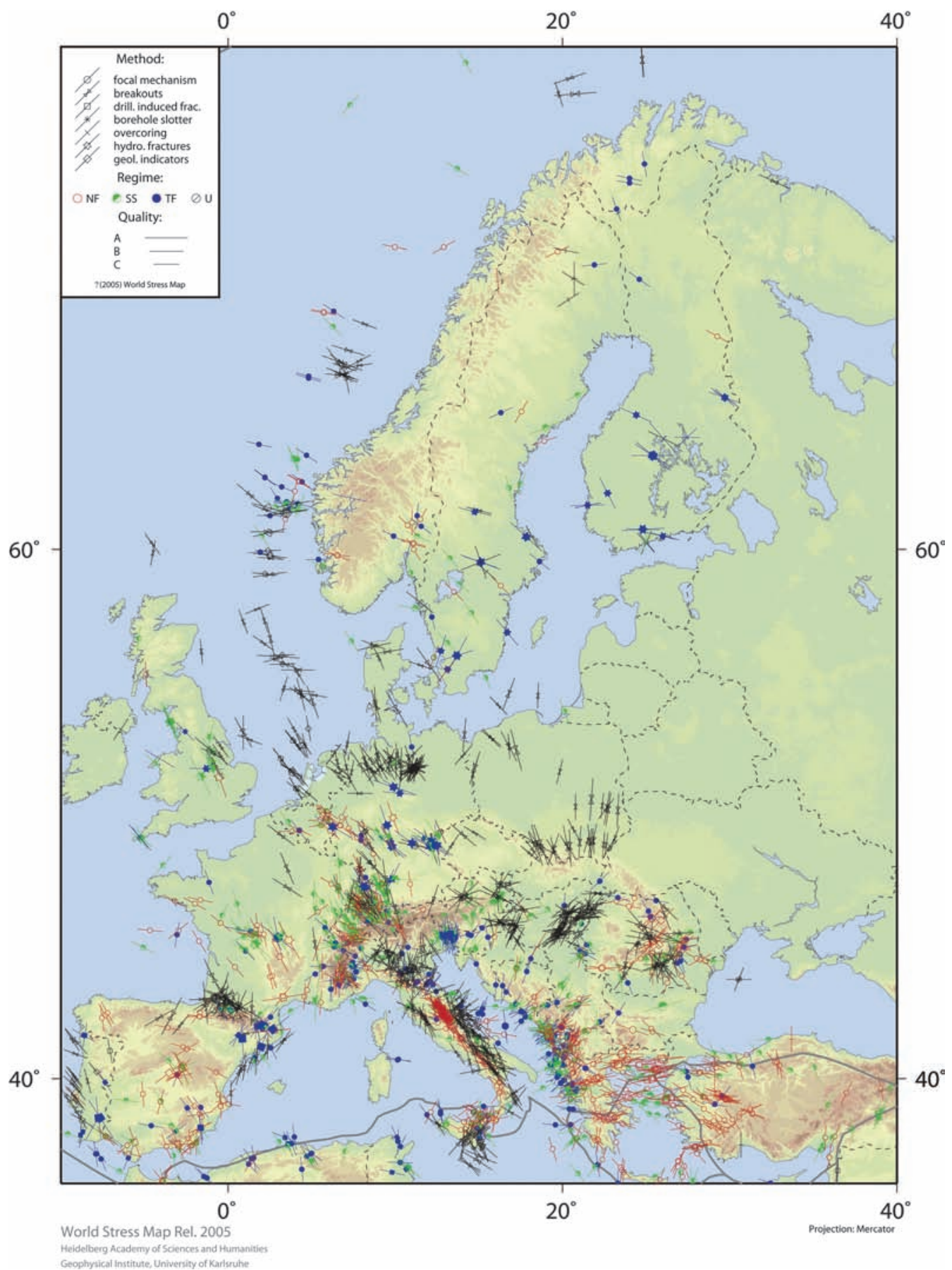

Fig. 7. Present day stress map for Europe. Extract from the World Stress Map (Reineker et al. 2005). Long axes of stress plots show orientation of present day maximum compressive stress from earthquake focal plane mechanisms, borehole breakouts and other sources. 
from the Alpine orogen by an intervening spreading ridge.

Further investigation of links between the Alpine deformation and the NE Atlantic structures would require a more in-depth examination of 'time and place' in the orogenic belt. Correlation with generalized Alpine phases is probably oversimplistic. During the orogeny different parts of the foldbelt were active at different times in terms of thrusting and nappe formation. This in turn caused varying penetration of deformation into the Central European foreland along the strike of orogenic belt at any given time. Furthermore, the conditions for long-distance transmission of stress are not fully understood. Ideally, this process would require coupling between the collisional plates at the subduction zone. The lithospheric level at which such coupling takes place, and whether this would correspond with a well defined phase of thrusting/nappe formation, are issues that remain to be resolved.

\section{Reactivation of basement lineaments}

The long-axes of the compressional domes on the NE Atlantic seaboard show a rough correspondence with those of the the Mesozoic basins, with a preponderance of NE-SW and north-south trends (Figs $1 \& 2$ ). It is thus a workable a priori assumption that the structures resulted from inversion of the Mesozoic basins by classic mechanisms such as basin-centre bulge, reverse reactivation and halfgraben extrusion. The Helland Hansen Arch (Figs 3 \& 6) appears to correspond well to this type of mechanism. On its NW flank, NW- or west-vergent folding is linked to reversely reactivated segments of the Fles Fault Complex, an easterly-verging Jurassic-Cretaceous normal fault system (Doré \& Lundin 1996). However, in most cases, evidence of classic inversion is essentially circumstantial (trend-based) and is not supported by a direct fault linkage. This principle is well illustrated in the UK portion of the Faroe-Shetland Basin (Davies et al. 2004; see also earlier work by Roberts 1989). Here, up to 17 elongate NE-SW and NNE-SSW highs, interpreted to have formed due to middle-late Miocene compression, appear to overlie the thickest parts of the Mesozoic basin system. The seismic evidence does not provide a conclusive link between these features and underlying basin faults. Evidence of reactivation is circumstantial (albeit strong) and is provided by thickness considerations (see above), trends and fold wavelengths.

In other cases there appears to be no link at all to a basin-parallel fault or half-graben. Examples include the Ormen Lange, Havsule Dome, and Modgunn Arch at the transition between the
Vøring and Møre Basins. The junction between these basins occurs at a diffuse NW-SE trending basin cross-cutting dislocation, the Jan Mayen Lineament (Blystad et al. 1995). This lineament also coincides with a marked offset between the two basin axes, and links northwestward with a major oceanic fracture zone, the East Jan Mayen Fracture Zone (Fig. 2). The domes appear to be arrayed along the length of the Jan Mayen Lineament, suggesting an association.

The NW lineaments are part of a structural suite that extends over the whole NE Atlantic margin (e.g. Lundin \& Rundhovde 1993; Rumph et al. 1993) and in the UK-Faroes sector includes the Judd, Erlend and Clair Transfers. They are generally presumed to have formed as transfer zones (cf. Morley et al. 1990), accommodating displacement between different rift segments during extension of the Mesozoic basins. They may in some cases have an older origin, having been predisposed to develop at major basement (Caledonian and older) dislocations; see for example Dicken (1992) on offshore British Isles, and Fichler et al. (1999) on offshore mid-Norway. Although workers on the UK and Faroes margin attribute the compressional structures primarily to buttressing against basin-parallel structures, these sources also provide evidence for implication of the NW-SE transfer suite. This influence may be mainly a function of the fact that the transfer zones affected the original basin configuration, and hence the location of any compressive reactivation (e.g. Johnson et al. 2005; Kimbell et al. 2005). In some instances, however, late Cenozoic strikeslip reactivation of $\mathrm{NW}-\mathrm{SE}$ zones such as the Magnus Lineament is suggested by changes in strike and mud diapirism (Johnson et al. 2005; Kimbell et al. 2005).

Dore \& Lundin (1996) suggested that the the driving force for reactivation of the NW-SE lineaments was ridge push from the Atlantic spreading centre. Following previous workers (e.g. Brekke \& Riis 1987) it was proposed that the main period of reactivation could be attributed to the change in spreading direction from NW-SE to a more eastwest vector that took place at the beginning of the Oligocene (Chron 13, 33 Ma: see geological history section). According to this hypothesis, the change in plate motion created a sinistral transpressive regime via shear adjustments along the $\mathrm{NW}-\mathrm{SE}$ lineaments. It was supported by the presence of an apparent sinistral wrench structural assemblage along the NW-SE lineaments, particularly the Jan Mayen Lineament (e.g. north-south trending folds with local east-west tensional faults). Doré \& Lundin (1996) suggested a similar strikeslip association of compressive structures with other NW-SE lineaments offshore mid-Norway 
(e.g. Vema Dome with the Surt Lineament, Hedda Dome with the Bivrost Lineament).

Subsequent work has led us to re-evaluate this hypothesis. Although the evidence for a sinistral wrench suite is still strong (on the mid-Norwegian shelf at least) the tie to the Chron 13 plate reorganization is less persuasive, for the following reasons: (1) new evidence from drilling and interpretation of 3D datasets emphasizes the importance of the early to middle Miocene phase of growth of the northsouth anticlines along the Jan Mayen Lineament (Ormen Lange Dome, Havsule Dome and Modgunn Arch), i.e. some 15-20 Ma after onset of plate reorganization; and (2) change in plate motion would not have affected the direction of ridge push, since this effect is a body force from the elevated spreading ridge. These arguments do not preclude reactivation of members of the NWSE transfer suite by either body forces such as ridge push or by directional forces associated with spreading such as basal drag-they simply de-emphasize the link between these potential mechanisms and plate reorganization.

The array of north-south anticlines along the diffuse onshore projection of the East Jan Mayen Fracture Zone (Fig. 2) remains a strong indicator of probable wrench movement along the lineament, from whatever cause. This observation encapsulates the basement reactivation argument. Although there is strong circumstantial evidence that basement structure was implicated in the formation of the compressional structures, basement lineaments were essentially conduits for expression of strain and not an a priori cause of the deformation.

\section{Plate driving forces}

Candidate driving forces for lithospheres plates are: (1) the plate boundary forces, i.e. ridge-push and slab-pull; and (2) shear traction (mantle-drag) forces excerted at the base of the lithosphere by the convecting asthenosphere. Ziegler (1993) suggested that interaction of mantle drag forces with deviatoric tensional stresses in the lithosphere above upwelling asthenosphere cells are important to the breakup of large continental masses such as Pangaea, whereas the plate boundary forces may play a more important role during continent dispersal.

The North Atlantic-Arctic evolved from overall northward propagation of the Central Atlantic spreading axis, possibly interacting with a separate Arctic spreading system. The current spreading axes separate North America from Eurasia; however, a three-plate system including Greenland existed for approximately $20 \mathrm{Ma}$ in the Eoceneearliest Oligocene. Disregarding pre-breakup rifting, the oldest plate separation in the NE Atlantic region dates back approximately to late Maastrichtian time (Chron 31, c. $68 \mathrm{Ma}$ ) when the Labrador Sea opened. Some $15 \mathrm{Ma}$ later, in early Eocene time (Chron 24b, c. $53 \mathrm{Ma}$ ), the NE Atlantic and Norwegian-Greenland Sea opened. The two arms of seafloor spreading, Labrador Sea and NE Atlantic, were kinematically linked with the Gakkel Ridge in the Eurasia Basin; both arms were active until earliest Oligocene time (Chron 13, c. $33 \mathrm{Ma}$ ).

The effect of opening the NE Atlantic was to translate Greenland north-northwestward. Greenland's triangular shape permitted it being squeezed by two opposed spreading forces, analogous to squeezing a lemon seed. As a result, Greenland impinged upon the Canadian Arctic islands and the SW Barents Sea margin, resulting in the Eurekan and West Spitsbergen orogenies (see earlier sections). The significance of this observation is that a plate-driving force capable of causing these orogenies would easily be able to create the low-strain passive margin domes. It appears possible to exclude traditional 'passive' mechanisms such as slab-pull as the driving force: we know of no evidence for a relict subduction zone within the Eurekan orogen. Ridge-push, which most published work suggests is only capable of generating stresses of approximately $2-3 \times 10^{12} \mathrm{~N} \mathrm{~m}^{-1}$ (Haxby \& Turcotte 1978; Dahlen 1981; Fleitout \& Froidevaux 1982; Kusznir 1991), is insufficient to have caused the observed compressional shortening in the Eurekan orogen. So what force caused the orogenies? Potential candidates include:

1) Ziegler's (1993) idea of constructive interference between plate boundary forces and overall lithospheric motion relative to the deep mantle. Palaeomagnetically-constrained plate tectonic reconstructions reveal that North America, Greenland, and Eurasia all travelled northwestward relative to the deep mantle, although simultaneously moving away from each other as a result of plate separation (Torsvik et al. 2001). During Eocene time (Chron 24b-13) when Greenland acted as a separate plate, the NE Atlantic arm of spreading could conceivably have interfered constructively with the overall lithospheric drift applied to Greenland, pushing Greenland into North America and causing the Eurekan Orogeny. However, the mechanism for this common overall motion of dispersing plates is poorly understood.

2) Bott's (1993) proposal of enhanced ridgepush from anomalously warm asthenosphere (basically a plume). The current anomalous elevation of the NE Atlantic spreading axis, above sea-level on Iceland, and the widespread positive North Atlantic geoid anomaly may reflect an upper mantle thermal anomaly. As for normal ridge-push forces, Bott's enhanced mantle-drag force ought to act 
symmetrically, i.e. affect both the Greenland and Eurasian plates. If one opts for the possibility that this force was responsible for the Eurekan Orogeny, it is still unclear why the more proximal areas along the NE Atlantic margins were only mildly deformed.

The model proposed by Kusznir et al. (2005) and Kusznir \& Karner (2007) for continental lithosphere thinning leading to continental breakup and seafloor spreading initiation predicts that for volcanic margins the young continental margin lithosphere is placed into horizontal compression. In this model, developed to explain apparent depthdependent stretching at continental margins, deformation and thinning of continental lithosphere leading to breakup occurs in response to an upwelling divergent flow field emanating from the asthenosphere. Such flow could occur ahead of the propagating tip of a spreading ridge or, locally, from a mantle plume. Differing breakup lithosphere geometries are explained through the interplay between the upwelling divergent flow field (with a velocity $V_{z}$ ) and the rate of plate separation $\left(V_{x}\right)$. During the formation of volcanic margins, $V_{z}$ is significantly larger than $V_{x}$ due to thermal buoyancy (Neilsen \& Hopper 2003) and the young continental margin lithosphere suffers horizontal compression during early seafloor spreading.

This model therefore holds the possibility of compression, which could be validated by searching for examples of contractional structures close to the margins and associated with breakup. In the NE Atlantic margin, this mechanism would be mainly expected to apply at time of breakup and shortly thereafter, when the upwelling flow field was close to, and acting upon, the margin. It may be a candidate for the earliest Cenozoic compressive deformation phases recorded off mid-Norway (Lundin \& Doré 2002) and in the Faroes-Rockall area (Boldreel \& Andersen 1998; Johnson et al. 2005) but is unable to explain later compressional structuring including the regional peak in the midMiocene (Fig. 4).

\section{Body forces}

Differences in topography and/or lithospheric density between adjacent areas, and the resulting lithostatic head, can create a horizontal pressure gradient and thus the potential for crustal deformation. Unless bordered by exceptionally high continental topography, the primary body force influencing passive margins is likely to be ridge push, i.e. the gravitational force exerted by a thermally elevated spreading ridge (eg Turcotte \& Schubert 1982). As indicated earlier, ridge-push is capable of generating stresses of approximately $2-3 \times 10^{12} \mathrm{~N} \mathrm{~m}^{-1}$ (Haxby \& Turcotte 1978;
Dahlen 1981; Fleitout \& Froidevaux 1982; Kusznir 1991), which could be enhanced in the region of an asthenosphere anomaly such as a mantle plume. These forces are capable of creating mild compressive deformation on the adjacent margin, depending on its structure and elevation. However, timing remains a critical problem. The Eocene-Oligocene inception of the compression does not appear to leave time for the generation of sufficient relief between the ocean ridge and the young rifted continental margin. In addition, young oceanic lithosphere might be too weak to serve as efficient stress guide and transmit stresses to the margin. More importantly, the episodic nature of the compression with a significant phase in the mid-Miocene seems difficult to attribute to ridge push, which should be a constant or gradually developing effect. To seek a solution, it is necessary to examine the interaction between the NE Atlantic ridges and Iceland during the Cenozoic.

Although the opening of the NE Atlantic and Norwegian-Greenland Sea can be described by a common pole of rotation (e.g. Talwani \& Eldholm 1977), it is well recognized that the central segment of the NE Atlantic spreading system, consisting of the Aegir and Kolbeinsey ridge pair, is more complicated. Prior to the abandonment of the Aegir Ridge, the asymmetric fan-shaped spreading of Aegir Ridge was compensated by opposed asymmetric spreading along the Kolbeinsey Ridge. Of key interest too is the time of abandonment of the Aegir Ridge and/or the time when spreading along the Kolbeinsey Ridge changed from a northward propagating pattern to 'orthogonal' opening described by the overall NE Atlantic pole of rotation. Unfortunately, the time of abandonment of the Aegir Ridge remains unclear since the anomaly of the central axis appears to be a fused mix of magnetic signatures post-dating Chron 13 (33 Ma) (Jung \& Vogt 1997). The final phase of spreading along the Aegir Ridge was ultraslow, and the exact time of abandonment depends on how slow one allows the rate to become (e.g. Breivik et al. 2006). Another option is indirectly to determine the time of abandonment by the onset of 'orthogonal' opening along the Kolbeinsey Ridge. This appears to have occurred near Chron 6a (c. $21 \mathrm{Ma}$ ). Stacked aeromagnetic flight tracks (Vogt et al. 1980) centred on Chron 4 reveal parallel anomalies out to Chron 6a, while Chron 6b deviates in orientation and is here interpreted to be the last anomaly related to northward fan-shaped spreading (cf. Nunns 1983; Lundin \& Doré 2005). Thus we argue that the Kolbeinsey Ridge had taken over most of the spreading from the Aegir Ridge by Chron 6a (c. $21 \mathrm{Ma}$, late early Miocene). The significance of this observation will become clear 
when we discuss (below) the distribution of domes on the adjacent Mid-Norwegian shelf.

We propose that there is a connection between the body force from the development of the Iceland Insular Margin and the widespread middle Miocene pulse of compression. Such an interpretation is attractive because: (1) the feature would seem to have potential for generation of a greater body force than a less elevated spreading ridge; and (2) it may provide a means to explain the onset of increased stress in mid-Cenozoic times. The interpretation is hampered, however, by the absence of conclusive dating of the Iceland Insular Margin. The offshore part of the plateau has not been sampled and age dated. An IODP drilling site in this area seems overdue.

The oldest basalts onshore Iceland are located along the west and east sides of the island and are of middle Miocene age (Jóhannesson \& Sæmundsson 1998). Northward projection of the well-defined magnetic isochrons related to the Reykjanes Ridges onto the Greenland-Faroes Ridge and the Iceland Plateau yields different ages against the west and east side of the plateau (approx. Chron 13 and Chron 20 respectively) (Fig. 8). Making the simple assumption that the west and east sides formed simultaneously it can be argued that at least the east side of the plateau is considerably younger than the substrate of the Greenland-Faroes Ridge. This would be the case if a surge of magmatism had caused flood basalts to spread out radially over pre-existing oceanic crust. Extending this argument further, we propose as a testable working hypothesis that the Iceland Insular Margin as expressed by current bathymetry was initiated in middle Miocene time during a major magmatic event. The build-up of the Iceland Insular Margin would have induced a body force directed radially towards the margins of the NE Atlantic.

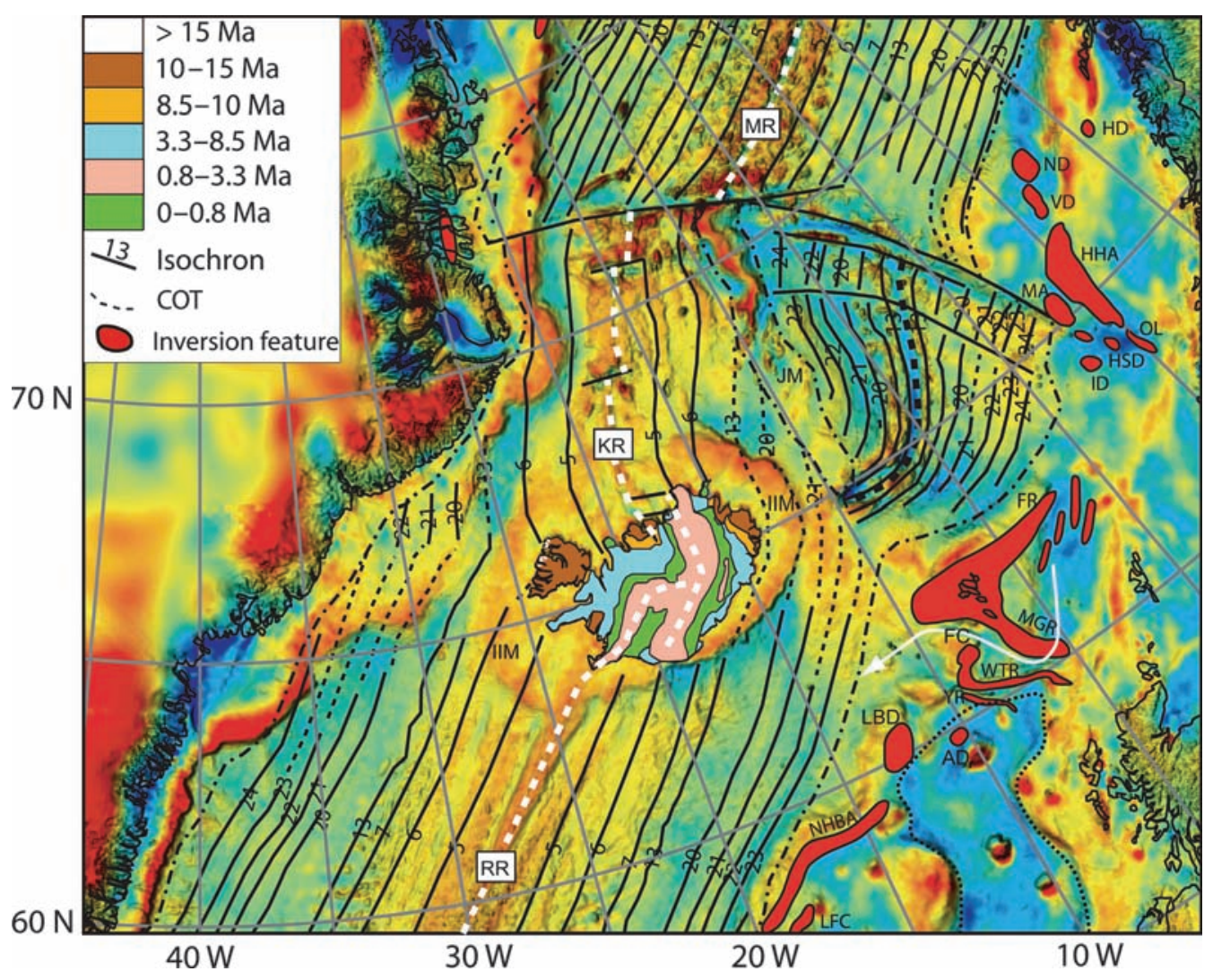

Fig. 8. Free air gravity draped on bathymetry and topography, with seafloor spreading isochrons, approximate continent-ocean transition, spreading axes and bedrock ages in Iceland from Jóhannesson \& Sæmundsson (1998). For abbreviations see Figure 1. Polar stereographic north projection. 
Body force generated by the Iceland Insular Margin

As indicated earlier, more accurately determining the time at which the present plateau developed could help to establish this link, since the structures developed spasmodically with an acme in the
mid-Miocene. Of equal importance is whether the elevated Iceland Insular Margin could have created enough body force to cause deformation of the margins.

Figure 9a shows geoid elevation relative for the Iceland-NE Atlantic area, using the EGM96 geoid model relative to the reference shape of the Earth

(a)
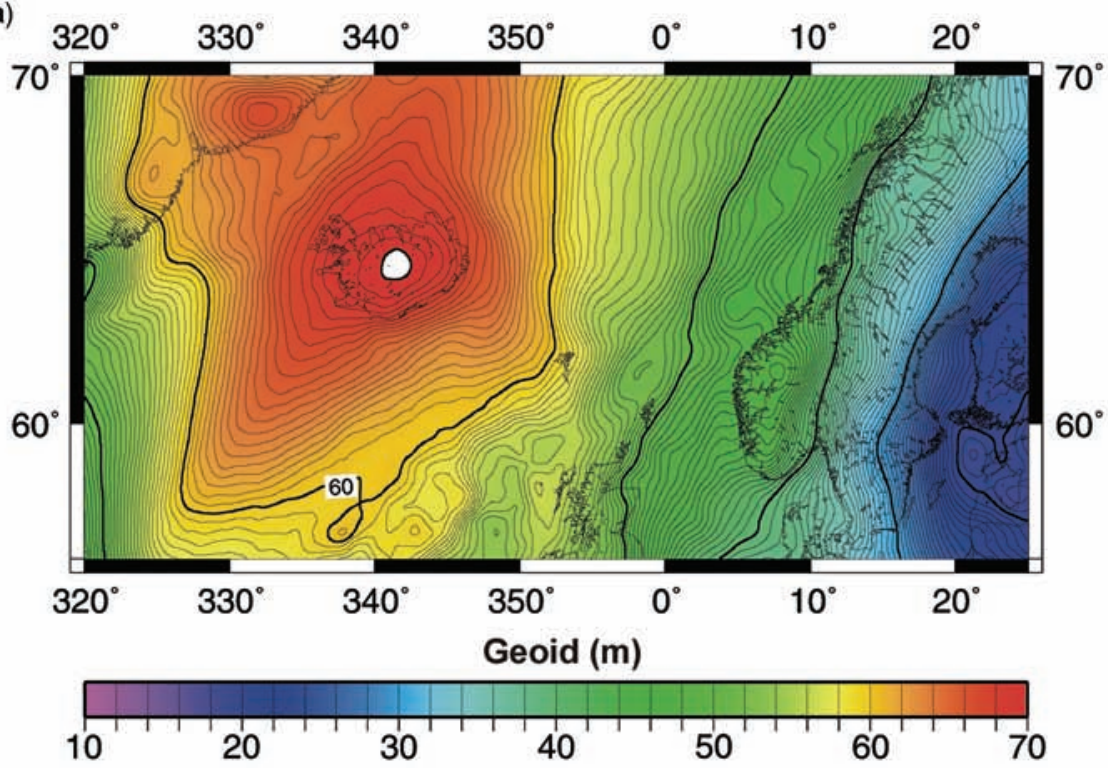

(b)
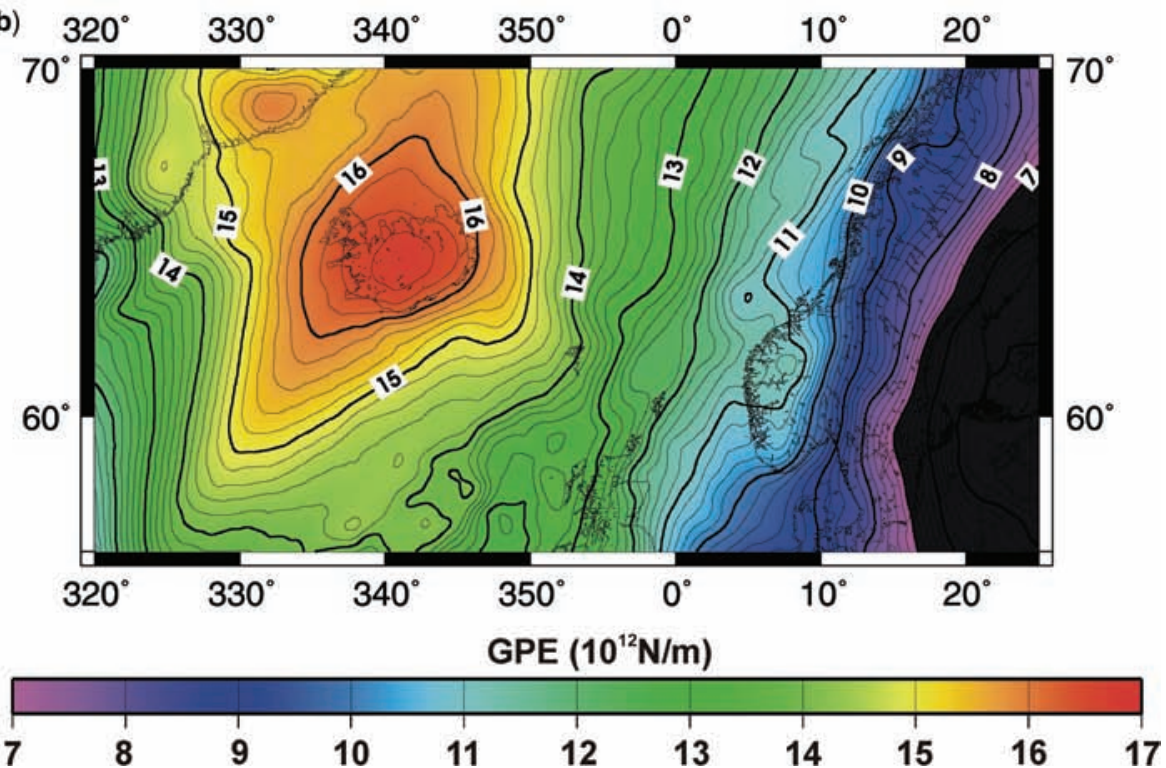

Fig. 9. (a) Geoid height anomaly map for the NE Atlantic, using the EGM96 geoid model. (b) Calculated gravitational potential energy based on (a). Regular Mercator Projection, central meridian $352.5^{\circ}$. 
(Lemoine et al. 1996). Using the assumption of local isostasy, gravitational potential energy values (GPE) can be directly derived from geoid undulations (Turcotte \& Schubert 1982). Bott (1991) demonstrated that the results obtained from this simplified approach do not differ significantly from those obtained applying more complex numerical models. The NE Atlantic GPE values are shown in Figure 9b. The difference in GPE between the Iceland Insular Margin and the adjacent Norwegian continental margin, and thus the force applied to the margin, is about $5 \times 10^{12} \mathrm{~N} \mathrm{~m}^{-1}$. Assuming that all the force is transmitted to a $c .100 \mathrm{~km}$-thick lithosphere and no dissipation takes place, a rough estimation for the horizontal stress gives $50 \mathrm{MPa}$ applied to the whole lithospheric column, or c.100 to $150 \mathrm{MPa}$ if we consider that the force concentrates on the mechanical boundary layer of the lithosphere (Parsons \& McKenzie 1978; Kusznir 1991). This value appears to be higher than needed to cause yielding and shortening of the basement (e.g. Kusznir 1991; Ranalli 1995).

Note that this calculation is for the fully-expanded geoid, which in turn represents signals from sources located both at lithosphere levels and greater depths. If the geoid is truncated at higher degrees and orders, or conversely for long wavelengths, we are able to eliminate the signals associated with deep sources, e.g. located at the core-mantle interface (Bowin 1991) that are unlikely to transmit stresses to the lithosphere directly. As a consequence lower stress magnitudes than proposed above would be calculated. On the other hand, geoid trucation can also result in eliminating longwavelength signals associated with relatively shallow sources (e.g. at asthenospheric levels) but having significant lateral extension. Thus, although our simple computation appears to show that the Iceland Insular Margin and associated mantle structure can create enough body force to cause deformation, the computed stress magnitudes rely on the true depth of the sources producing the geoid anomaly centred at the location of the plateau and appear to be dependent on the degree of coupling between the lithosphere and asthenoshere.

\section{What governs the location of the compressional structures?}

Assuming transmission of this stress through the lithosphere, it is reasonable to assume that it is propagated through the basement rather than through the young and ductile Cretaceous-Cenozoic basin fills on the margin. What factor, therefore, governs the position at which the basement will fail, either through new simple shear or through re-activation of existing shears, and thereby generating compressional structures in the cover rocks? In general, the hotter the basement, the lower the stress levels stress levels required for fracturing to take place (Ranalli 1995). On a passive margin, hottest (and therefore weakest) basement would logically be found where the crystalline crust is thinnest and blanketed by the thickest overlying sedimentary pile.

To test this supposition, we have examined sedimentary thicknesses on the Norwegian Atlantic margin. These are plotted in Figure 10, the values broadly derived from the work of Ebbing et al. (2006). From the depth to basement map we generated a total sediment thickness map. From this map in turn we subtracted the thickness of the PlioPleistocene Naust formation (Riise et al. 2005) in order to reveal the pre-glacial sediment thicknesses. Also shown on Figure 10 are the approximate locations and shapes of the Cenozoic domal structures and the weakly inverted Vigrid and Någrind synclines, and it can be seen that there is a reasonably good correspondence between the structures and the sedimentary 'thicks' representing the deepest Cretaceous-Cenozoic basins. An exception is the more inboard basin of the Halten Terrace, where compressional structures are minor or absent. The thick sedimentary succession of the Halten Terrace is mainly of Triassic-Jurassic age, and it is therefore possible that the thinnest, hottest and weakest basement is to be found under the younger, more recently stretched Vøring Basin. This idea is also supported by geothermal gradients from unpublished industry well data. Although these data are generally recorded on structural 'highs' and should be regarded with some caution, the data available for the Norwegian margin show gradients in the order of $30-40{ }^{\circ} \mathrm{C} \mathrm{km}^{-1}$ for the shelf, increasing to $40-50{ }^{\circ} \mathrm{C} \mathrm{km}^{-1}$ in the deep basins.

Therefore, there are reasonable grounds to support the speculation that the hottest basement under the young, deep sedimentary basins of the margin was predisposed to shear under the influence of body forces from the adjacent ocean, with the largest contribution to these forces in the NE Atlantic coming from the Iceland Insular Margin. This force may not, on the other hand, have been sufficient to deform cooler basement areas. Our next research step will be to carry out numerical simulations to test whether this hypothesis, at present only supported by empirical observation, can be be sustained at the likely ranges of horizontal stress and basement temperature on the NE Atlantic margin. It also remains to be seen whether this idea forms a general explanation for compressive deformation of passive margins in the absence of nearby orogenic influences. 


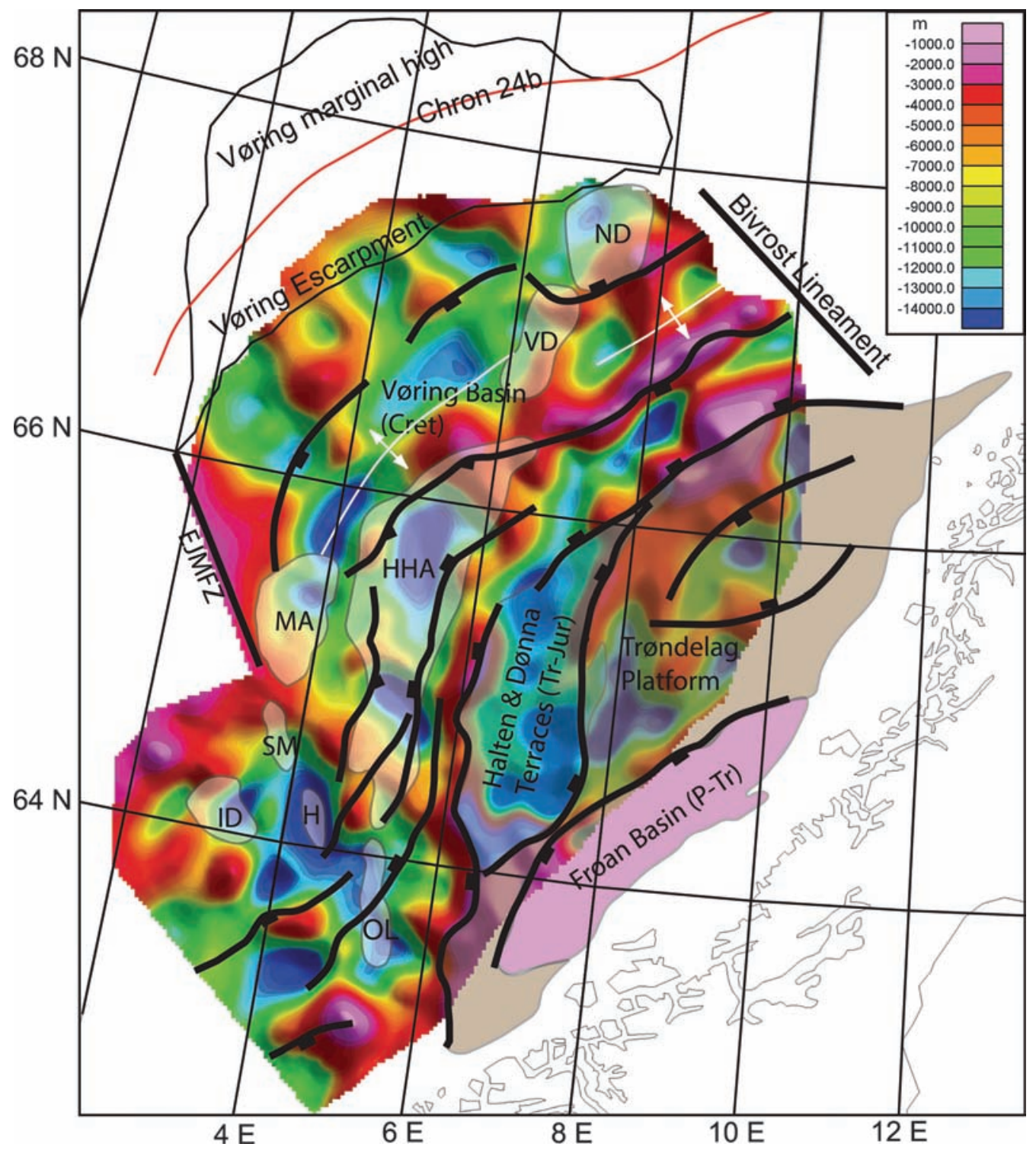

Fig. 10. Total sediment thickness map (excluding the thickness of the Plio-Pleistocene Naust Fm), overlain with main structural provinces, main fault systems and inversion features. A reasonably good correspondence between the inversion structures and the deepest Cretaceous-Cenozoic Basins is evident. For abbreviations see Figures 1 \& 2. UTM Zone 33 projection.

Why are there few or no compressional features along the Mфre margin?

The distribution of Cenozoic compressional features along the NE Atlantic margins is notable for the lack of such features along the Møre margin of
Norway, in spite of a thick and presumably easily deformable sedimentary fill in the Møre Basin, up to $17 \mathrm{~km}$ in axial parts. If there is indeed a connection with body force generated from the Iceland Plateau, the Møre Basin should be in prime position for compression, and yet little is observed. 


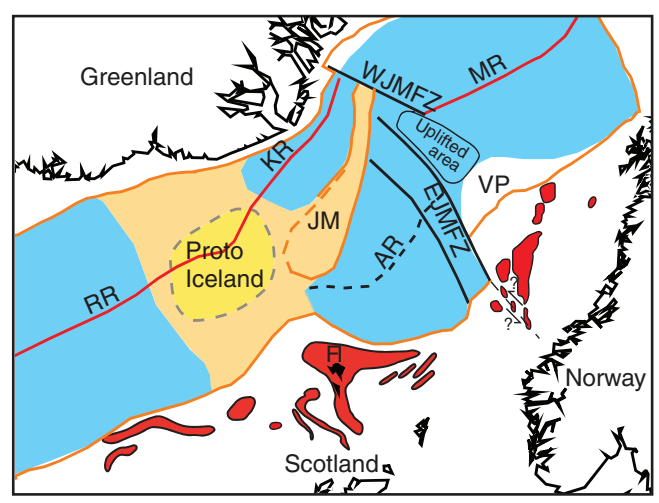

Fig. 11. Simplified crustal thickness map at Middle Miocene time (18 Ma), with inversion features marked in red. Abbreviations: AR, Aegir Ridge; EJMFZ, East Jan Mayen Fracture Zone; FI, Faroe Islands; JM, Jan Mayen microcontinent; MR, Mohns Ridge; KR, Kolbeinsey Ridge; RR, Reykjanes Ridge; VP, Vøring Plateau; WJMFZ, West Jan Mayen Fracture Zone. Blue, thin crust; orange, thick crust; yellow, significantly thicker crust. Area marked 'uplifted' represents Miocene uplift (Breivik et al. 2006). Simplified after Greenhalgh \& Kusznir 2007.

Notably, this portion of the margin lies inboard of the extinct Aegir Ridge, suggesting a causative relationship. We suggest that the development of the Iceland Insular Margin not only provided the gravitational force responsible for the compressional deformation, but also was the decisive factor making the Kolbeinsey Ridge succeed over the Aegir Ridge and thereby generate the single spreading ridge in the central segment of the NE Atlantic. If so, the Aegir Ridge conceivably absorbed the compression by slowing down to ultraslow spreading, thereby shielding the Møre margin from this force (Figs 5c \& 11).

A potential flaw in this argument is that the Aegir Ridge would also interpose between the Iceland Insular Margin and the Vøring Basin, where compressional domes are developed. This objection could be overcome if there was strain partitioning by lateral movement along the East Jan Mayen Fracture Zone and its margin prolongation, the Jan Mayen Lineament (Figs 2 \& 11). This could conceivably allow transmission of stress to the Vøring Basin while allowing accomodating by shortening around the Aegir Ridge. The oceanic bathymetric high identified by Breivik et al. (2006) just NE of the East Jan Mayen Fracture Zone ('uplifted area' in Fig. 11) has been identified as overthickened oceanic crust associated with Late Miocene underplating, but speculatively may also be a result of strain accomodation along the fracture zone.

\section{Conclusions}

(1) A suite of compressional structures is now welldocumented on the Faroes-Rockall and MidNorwegian passive continental margins. Minor representatives of the suite have also been identified onshore SE Greenland and offshore NE Greenland. Although developed at very low strain levels, the structures include domes of substantial areal extent and structural relief. They are therefore interesting as petroleum exploration targets.

(2) By context, the structures are different from the gravity-induced foldbelts commonly found in the deep-water delta front settings elsewhere around the Atlantic (West Africa, Brazil and Gulf of Mexico).

(3) The structures developed from early Eocene breakup to Recent times, but underwent episodes of greater activity. A marked compressive episode in the middle Miocene is recorded by authorities working on Rockall, the Faroe-Shetland Basin and the Norwegian Sea. This episode also coincided with the development of a continuous Atlantic spreading system from the Laptev Sea in the Arctic to the southernmost South Atlantic. We further suggest a link with the inception of the Iceland Insular Margin, generally believed to have taken place in the Miocene but poorly constrained by dating. Conceivably, the development of this melting anomaly could reflect linkage of Arctic and Atlantic mantle convection systems.

(4) Sedimentary loading, either from progradation of thick Plio-Pleistocene deposits or consisting of simple differential compaction, enhanced the flanks of some or all of the compressional structures. This mechanism, however, cannot be used to model all of the relief of the features and is unlikely as a primary cause of the structures; an initial tectonic impetus is necessary.

(5) A mechanism involving far-field transmission of orogenic stress from the Alpine orogen to the south and/or the West SpitsbergenEurekan orogen to the north remains attractive, not least because of the episodic nature of the deformation. A problem with the Alpine hypothesis is the apparent absence of notable compression in intervening areas such as the northern North Sea. The West Spitsbergen-Eurekan system is separated from the area of interest by the Senja Fracture Zone, and evidence of stress transmission lengthways along the shelf by (for example) strike-slip is not observed. We have examined the driving force generating these northern orogenies, because it appears that they occurred in the absence of traditional 'passive' plate-driving mechanisms such as slab pull, suggesting in turn generation of compression by an 'active' drive from the spreading 
ridges. We have not yet, however, settled on a convincing explanation for this apparent anomaly.

(6) There is a strong association throughout the margin between the compressional structures and the grain of the underlying Mesozoic basins and basement. Cross-cutting NW-SE transfer zones and lineaments also appear to have influenced some structures, with the association of the Jan Mayen Lineament with domes such as Ormen Lange being particularly impressive. Basement reactivation appears to influence strain localization, but does not provide an explanation for the primary cause of the compressive stress.

(7) Recent models of continental breakup involving divergent asthenospheric flow are capable of inducing compressive deformation on the margins, specifically where the rate of divergent flow exceeds the rate of plate separation, as postulated to be the case on volcanic margins. Compression in such cases would primarily be expected at or close to time of breakup, and has the potential to explain early Cenozoic deformation recorded offshore mid-Norway and in the Faroes-Rockall area. It would not explain the acme of the NE Atlantic margin compressive structures in midCenozoic time.

(8) Ridge push, generally thought to be the dominant body force affecting passive margins, can in certain circumstances generate enough force to cause mild deformation. However, this mechanism alone does not seem to be able to explain either the episodic timing or the location of the structures.

(9) We suggest that development of the topographically high Iceland Insular Margin, currently rather loosely constrained to a magmatic event in the Miocene, may be strongly associated with development of the structures. This idea has the potential to explain the episodic development, specifically the pulse in the early middle Miocene, and the location of the structures in an apparent arc around Iceland.

(10) Modelling of the Gravitational Potential Energy (GPE) of the geoid undulation associated with the Iceland Insular Margin shows that enough horizontal stress can be generated to deform adjacent margins. This result depends on the depth filter applied, with greater forces deriving from greater lithosphere depths. Such values rely on the deep asthenospheric root of the plateau as well as the surface topography, and appear to be dependent on the degree of coupling between the lithosphere and asthenosphere.

(11) Accomodation of compression along the ultraslow-spreading Aegir Ridge, or in the anomalously thin oceanic crust of the adjacent Norway Basin, may explain the puzzling near-absence of compressional structures from the Møre Basin.
This model would require strain partitioning along the Jan Mayen Lineament, and idea that is strongly supported by the series of probably wrench-related anticlines along the lineament.

(12) We propose that the locus of the structures is predisposed by the position of hottest, weakest and most easily sheared basement, usually in the axial Cretaceous-Cenozoic depocentres. A superimposition of sedimentary thickness and the Cenozoic domes on the mid-Norway margin provides good empirical support for this hypothesis. Whether this idea could be a paradigm for passive margin compression depends on testing of additional areas.

(13) Critical future research is proposed to include: (a) further, more sophisticated modelling of the potential body force from the Iceland Insular Margin; (b) numerical simulations to determine whether there is indeed a connection between the locus of the compressive structures, the likely ranges of horizontal stress and basement temperature on the NE Atlantic margin; and (c) more precise dating of the Iceland Insular Margin, a surprisingly neglected line of research that could be accomplished via an IODP site or other offshore drilling.

The authors thank Howard Johnson and Martyn Stoker for thorough and constructive reviews. We gratefully acknowledge the use of the SPlates plate reconstruction software, developed in collaboration with the Geological Survey of Norway, and thank Carmen Gaina for her efforts in this project. The plate reconstructions were carried out in-house and we thank Phil Ball for his input to this. Grateful thanks to Berit Hjelstuen for allowing us to reproduce the section in Figure 6.

\section{References}

Berástegui, X., Banks, C. J., Puig, C., Taberner, C., Waltham, D. \& Fernández, M. 1998. Lateral diapiric emplacement of Triassic evaporites at the southern margin of the Guadalquivir Basin, Spain. In: Mascle, A., Puigdefábregas, C., Luterbacher, H. P. \& Fernández, M. (eds) Cenozoic Foreland Basins of Western Europe. Geological Society, London, Special Publications, 134, 49-68.

Blystad, P., BrekKe, H., Færseth, R. B., Larsen, B. T., Skogseid, J. \& TøRudbakken, B. 1995. Structural elements of the Norwegian continental shelf. Part II: The Norwegian Sea region. Norwegian Petroleum Directorate Bulletin, 8.

Boldreel, L. O. \& Andersen, M. S. 1993. Late Paleocene to Miocene compression in the Faroe-Rockall area. In: PARKer, J. R. (ed.) Petroleum Geology of Northwest Europe. Proceedings of the 4th Conference. Geological Society, London, 1025-1034.

Boldreel, L. O. \& Andersen, M. S. 1998. Tertiary compressional structures on the Faeroe-Rockall Plateau in relation to northeast Atlantic ridge-push 
and Alpine foreland stresses. Tectonophysics, 300, $13-28$.

BotT, M. H. P. 1991. Ridge push and associate plate interior stress in normal and hot spot regions. Tectonophysics, 200, 17-32.

BотT, M. H. P. 1993. Modelling the plate-driving mechanism. Journal of the Geological Society of London, 150, 941-951.

Bowin, C. 1991. The Earth's gravity field and plate tectonics, Tectonophysics, 187, 69-89.

BreiviK, A. J., Muelde, R., Faleide, J. I. \& Murai, Y. 2006. Rates of continental breakup magmatism and seafloor spreading in the Norway Basin - Iceland plume interaction. Journal of Geophysical Research, 111, B07102, doi:10.1029/2005JB004004.

BREKKE, H. 2000. The tectonic evolution of the Norwegian Sea Continental Margin with emphasis on the Vøring and Møre Basins. In: NøTtVEDT, A. (ed.) Dynamics of the Norwegian Margin. Geological Society, London, Special Publications, 167, 327-378.

BREKKE, H. \& RIIS, F. 1987. Tectonics and basin evolution of the Norwegian shelf between $62^{\circ}$ and $72^{\circ} \mathrm{N}$. Norsk Geologisk Tidskrift, 67, 295-321.

Brozena, J. M., Childers, V. A., Lawver, L. A., Gahagan, L. M., Forsberg, R., Faleide, J. I. \& ELDHOLM, O. 2003. New aerogeophysical study of the Eurasia Basin and Lomonosov Ridge: implications for basin development. Geology, 31, 825-828.

Chalmers, J. A. \& Pulvertaft, T. C. R. 2001. Development of the continental margins of the Labrador Sea: a review. In: Wilson, R. C. L., WhitMARSh, R. B., TAYLOR, B. \& FROITZHEIM, N. (eds) Non-Volcanic Rifting of Continental Margins: A Comparison of Evidence from Land and Sea. Geological Society, London, Special Publications, 187, $77-105$.

Cloetingh, S., Gradstein, F. M., Kooi, H., Grant, A. C. \& KAMINSKI, M. 1990. Plate reorganization: a cause of rapid late Neogene subsidence and sedimentation around the North Atlantic. Journal of Geological Society, London, 147, 495-506.

Cramez, C. \& JACKSON, M. P. A. 2000. Superposed deformation straddling the continental-oceanic transition in deep-water Angola. Marine and Petroleum Geology, 17, 1095-1109.

DAHLEN, F. A. 1981. Isostasy and the ambient state of stress in the oceanic lithosphere. Journal of Geophysical Research, 86, 7801-7807.

Davies, R. J., Cloke, I., CARTwright, J., Robinson, A. \& FERRERO, C. 2004. Post-breakup compression of a passive margin and its impact on hydrocarbon prospectivity: and example from the Tertiary of the Faroe-Shetland Basin, United Kingdom. American Association of Petroleum Geologists Bulletin, 88, $1-20$.

Dicken, A. P. 1992. Evidence for an Early Proterozoic crustal province in the North Atlantic region. Journal of Geological Society, London, 149, 483-486.

DoRÉ, A. G. \& Lundin, E. R. 1996. Cenozoic compressional structures on the NE Atlantic margin: nature, origin, and potential significance for hydrocarbon exploration. Petroleum Geoscience, 2, 299-311.

Doré, A. G., Lundin, E. R., Jensen, L. N., Birkeland, Ø., Eliassen, P. E. \& Fichler, C. 1999. Principal tectonic events in the evolution of the northwest Eurpoean Atlantic margin. In: FleET, A. J. \& Boldy, S. A. R. (eds) Petroleum Geology of Northwest Europe. Proceedings of the 5th Conference. Geological Society, London, 41-61.

Ebbing, J., Lundin, E., Olesen, O. \& Hansen, K. 2006. The mid-Norwegian margin: a discussion of crustal lineaments, mafic intrusions, and remnants of the Caledonian root by 3D density modelling and structural interpretation. Journal of the Geological Society, London, 163, 47-59.

Eidvin, T., Bugge, T. \& Smelror, M. 2007. The Molo Formation, deposited by coastal progradation on the inner Mid-Norwegian continental shelf, coeval with the Kai Formation to the west and the Utsira Formation in the North Sea. Norwegian Journal of Geology, 87, 75-142.

Ellen, S. M. O. 2002. Geological Map, Land and Sea Areas of Northern Europe. Scale 1:4 million. Geological Survey of Norway.

Engen, Ø., FAleide, J. I. \& Dyreng, T. K. (2008). Opening of the Fram Strait gateway; a review of plate tectonic constraints: Tectonophysics.

EYLES, N. 1996. Passive margin uplift around the North Atlantic region and its role in Northern Hemisphere late Cenozoic glaciation. Geology, 24, 103-106.

Faleide, J. I., Myhre, A. M. \& Eldholm, O. 1988. Eraly Tertiary volcanism at the Western Barents Sea margin. In: MORTON, A. C. \& PARSON, L. M. (eds) Early Tertiary Volcanism and the Opening of the NE Atlantic. Geological Society, London, Special Publications, 39, 135-146.

Faleide, J. I., VÅGnes, E. \& Gudlaugsson, S. T. 1993. Late Mesozoic-Cenozoic evolution of the south-western Barents Sea in a regional rift-shear tectonic setting. Marine and Petroleum Geology, 10, $186-214$.

Feden, R. H., Vogt, P. R. \& Fleming, H. S. 1979. Magnetic and bathymetric evidence for the 'Yermak hot spot' northwest of Svalbard in the Arctic Basin. Earth and Planetary Science Letters, 44, 18-38.

Fichler, C., Rundhovde, E., Olesen, O., SÆther, B. M., Rueslåtten, H., Lundin, E. \& Doré, A. G. 1999. Regional tectonic interpretation of image enhanced gravity and magnetic data covering the mid-Norwegian shelf and adjacent mainland. Tectonophysics, 306, 183-197.

Fleitout, L. \& Froidevaux, C. 1982. Tectonics and topography for a lithosphere containing density heterogeneities. Tectonics, 1, 21-56.

Gaina, C., Roest, W.R. \& Muller, R.D. 2002. Late Cretaceous-Cenozoic deformation of Northeast Asia. Earth and Planetary Science Letters, 197, 273-286.

Gaina, C., Torsvik, T. H., Redfield, T. F. ET AL. 2006. Frontier Science and Exploration: the Atlantic-Arctic. Norwegian Geological Survey, report 2006.077.

Gernigon, L., Ringenbach, J. C., Planke, S., Le Gall, B. \& Jonquet-Kolstø, H. 2003. Extension, crustal structure and magmatism at the outer Vøring Basin, Norwegian margin. Journal of the Geological Society, 160, 197-208. 
Gómez, M. \& Vergés, J. 2005. Quantifying the contribution of tectonics vs. differential compaction in the development of domes along the Mid-Norwegian Atlantic margin. Basin Research, 17, 289-310.

Greenhalgh, E. E. \& KusZniR, N. J. 2007. Evidence for thin oceanic crust on the extinct Aegir Ridge, Norwegian Basin, NE Atlantic derived from satellite gravity inversion. Geophysical Research Letters, 34, L06305, doi:10.1029/2007GL029440.

Hamann, N. E., Wittaker, R. C. \& Stemmerik, L. 2005. Geological development of the Northeast Greenland Shelf. In: Doré, A. G. \& Vining, B. A. (eds) Petroleum Geology: North-West Europe and Global Perspectives. Proceedings of the 6th Petroleum Geology Conference. Geological Society, London, 887-902.

HaXby, W. F. \& TurcotTe, D. L. 1978. On isostatic geoid anomalies. Journal of Geophysical Research, 83, $5473-5478$.

HENRIKSEN, S. \& Weimer, P. 1996. High-frequency depositional sequences and stratal stacking patterns in Lower Pliocene coastal deltas, mid-Norwegian continental shelf. American Association of Petroleum Geologists Bulletin, 80, 1867-1895.

Huelstuen, B. O., Sejrup, H. P., Haflidason, H., BERG, K. \& BRYN, P. 2004. Neogene and Quaternary depositional environments on the Norwegian continental margin, $62^{\circ} \mathrm{N}-68^{\circ} \mathrm{N}$. Marine Geology, 213, 257-276.

Jones, S. M. \& Maclennan, J. 2005. Crustal flow beneath Iceland. Journal of Geophysical Research, 110, B9, doi:10.1029/2004JB003592.

Johnson, H., Ritchie, J. D., Hitchen, K., McInroy, D. B. \& Kimbell, G. S. 2005. Aspects of the Cenozoic deformational history of the Northeast FaroeShetland Basin, Wyville-Thomson Ridge and Hatton Bank areas. In: DoRÉ, A. G. \& Vining, B. A. (eds) Petroleum Geology: North-West Europe and Global Perspectives. Proceedings of the 6th Petroleum Geology Conference. Geological Society, London, 993-1008.

JóHANNESSON, H. \& SÆMUNDSSON, K. 1998. Geological map of Iceland. Iceland Institute of Natural History, Reykjavik. Scale 1:500 000.

Jordt, H., Thyberg, B.I. \& NøTTVEdT, A. 2000. Cenozoic evolution of the central and northern North Sea with focus on differential vertical movements of the basin floor and surrounding clastic source areas. In: NøtTvedt, A. (ed.) Dynamics of the Norwegian Margin. Geological Society, London, Special Publications, 167, 219-243.

JUnG, W.-Y. \& VogT, P. R. 1997. A gravity and magnetic study of the extinct Aegir Ridge, Norwegian Sea. Journal of Geophysyical Research, 102, 5065-5089.

Kimbell, G. S., Ritchie, J. D., Johnson, H. \& GAtLIFF, R. W. 2005. Controls on the structure and evolution of the NE Atlantic margin revealed by regional potential field imaging and $3 \mathrm{D}$ modelling. In: Doré, A. G. \& Vining, B. A. (eds) Petroleum Geology: North-West Europe and Global Perspectives. Proceedings of the 6th Petroleum Geology Conference. Geological Society, London, 933-945.

KJeldstad, A., Skogseid, J., Langtangen, H. P., BJøRLYKKE，K. \& HøEG，K. 2003. Differential loading by prograding sedimentary wedges on continental margins: An arch-forming mechanism. Journal of Geophysical Research, 108, B1, 2036. doi:10.1029/2001JB001145.

Kristoffersen, Y.\& TALWANI, M. 1977. Extinct triple junction south of Greenland and the Tertiary motion of Greenland relative to North America. Geological Society of America Bulletin, 88, 1037-1049.

KUSZNIR, N. J. 1991. The distribution of stress with depth in the lithosphere: thermo-rheological and geodynamic constraints. Philosophical Transactions of the Royal Society, 337, 95-110.

Kusznir, N. J., Hunsdale, R. \& Roberts, A. M. iSIMM Team 2005. Timing and magnitude of depth dependent lithosphere stretching on the S. Lofoten and N. Vøring continental margins offshore MidNorway: implications for subsidence and hydrocarbon maturation at volcanic rifted margins. In: DoRÉ, A. G. \& Vining, B. A. (eds) Petroleum Geology: NorthWest Europe and Global Perspectives. Proceedings of the 6th Petroleum Geology Conference. Geological Society, London, 767-783.

KuszniR, N. J. \& Karner, G. D. 2007. Continental lithosphere thinning leading to breakup and rifted margin formation in response to upwelling divergent flow: application to the Woodlark Basin, Newfoundland and Iberia Margins. In: KARner, G. D., Manatschal, G. \& Pinheiro, L. M. (eds) Imaging, Mapping and Modelling Continental Lithosphere Extension and Breakup. Geological Society, London, Special Publications, 282, 389-419.

Lear, C. H., Rosenthal, Y. \& Wright, J. D. 2003. The closing of a seaway: ocean water masses and global climate change. Earth and Planetary Sciences, 210, 425-436.

Lemoine, F. G., Smith, D., Smith, R. ET AL. 1996. EGM96, The NASA GSFC and NIMA Joint Geopotential Model. Proceedings of the International Symposium on Gravity, Geoid, and Marine Geodesy, Tokyo, Japan, September 30-October 4, 1996.

Louden, K. E., Osler, J. C., Srisastava, S. P. \& KeEN, C. E. 1996. Formation of oceanic crust at loe spreading rates: new constraints from an extinct spreading centre in the Labrador Sea. Geology, 24, $771-774$

Løseth, H. \& Henriksen, S. 2005. A Middle to Late Miocene compression phase along the Norwegian passive margin. In: Doré, A. G. \& Vining, B. A. (eds) Petroleum Geology: North-West Europe and Global Perspectives. Proccedings of the 6th Petroleum Geology Conference. Geological Society, London, $845-859$.

LUNDIN, E. R. 2002. Atlantic-Arctic seafloor spreading history. In: EIDE, E. A. (coord.) BATLAS - Mid Norway plate reconstructions atlas with global and Atlantic perspectives. Geological Survey of Norway, $40-47$.

Lundin, E. R. \& Doré, A. G. 1997. A tectonic model for the Norwegian passive margin with implications for the NE Atlantic: Early Cretaceous to break-up. Journal of the Geological Society, London, 154, 545-550.

Lundin, E. \& Doré, A. G. 2002. Mid-Cenozoic post-breakup deformation in the 'passive' margins bordering the Norwegian-Greenland Sea. Marine and Petroleum Geology, 19, 79-93. 
Lundin, E. R. \& Doré, A. G. 2005. NE-Atlantic break-up: a re-examination of the Iceland mantle plume model and the Atlantic-Arctic linkage. In: Doré, A. G. \& Vining, B. A. (eds) North-West European Petroleum Geology and Global Perspectives. Proceedings of the 6th Conference. Geological Society, London, 739-754.

LUNDIN, E. R. \& RUNDHOVDE, E. 1993. Structural domains in the Møre Basin, Norway - from digital images of aeromagnetic data. EAPG 5th Annual Convention, Stavanger, Annual Convention Official Program, EO37.

Martinsen, O. J., Bøen, F., Charnock, M. A., Mangerud, G. \& Nøttvedt, A. 1999. Cenozoic development of the Norwegian margin $60-64^{\circ} \mathrm{N}$ : sequences and sedimentary response to variable basin physiography and tectonic setting. In: FLEET, A. J. \& Boldy, S. A. R. (eds) Petroleum Geology of Northwest Europe. Proceedings of the 5th Conference. Geological Society, London, 293-304.

MCClay, K. R., Dooley, T. \& Lewis, G. 1998. Analog models of progradational delta systems. Geology, 26, 771-774.

Mohriak, W. U., Bassetto, M. \& Vieira, I. S. 1998. Crustal architecture and tectonic evolution of the Sergipe-Alagoas-Jacúipe Basins, offshore northern Brazil. Tectonophysics, 288, 199-220.

Mohriak, W. U., Rosendahl, B. R., Turner, J. P. \& VALENTE, S. C. 2002. Crustal architecture of South Atlantic margins. In: Menzies, M. A., Klemperer, S. L., Ebinger, C. J. \& BAKer, J. (eds) Volcanic Rifted Margins. Boulder, Colorado. Geological Society of America Special Paper 362, 159-202.

Morley, C. K., Nelson, R. A., Patton, T. \& Munn, S. G. 1990. Transfer zones in the East Africa rift system and their relevance to hydrocarbon exploration in rifts. American Association of Petroleum Geologists Bulletin, 74, 1234-1253.

Mosar, J., Lewis, G. \& TorsviK, T. H. 2002. North Atlantic sea-floor spreading rates: implications for the Tertiary development of inversion structures of the Norwegian-Greenland Sea. Journal of the Geological Society, London, 159, 503-515.

Nielsen, T. K. \& HopPER, J. R. 2002. Formation of volcanic rifted margins: Are temperature anomalies required? Geophysical Research Letters, 29, 2022-2025.

NunNs, A. G. 1983. Plate tectonic evolution of the Greenland-Scotland Ridge and surrounding regions. In: Botт, M. H. P., Saxov, S., Talwani, M. \& Thiede, J. (eds) Structure and Development of the Greenland-Scotland Ridge: New Methods and Concepts. Plenum Press, New York, 11-30.

OAKEY, G. 1994. A structural fabric defined by topographic lineaments: correlation with tertiary deformation of Ellesmere and Axel Heiberg Islands, Canadian Arctic. Journal of Geophysical Research, 99(B10), 20,311-20,321.

OAKEY, G. N. 2005. Cenozoic evolution and lithosphere dynamics of the Baffin Bay - Nares Strait region of Arctic Canada and Greenland. Ph.D. thesis, Vrije Universiteit, The Netherlands.

Parsons, B. \& MCKenZIE, D. 1978. Mantle convection and the thermal structure of the plates, Journal of Geophysical Research 83, 4485-4496.
PASCAL, C. \& GABRIElSEN, R. H. 2001. Numerical modelling of Cenozoic stress patterns in the Mid Norwegian Margin and the northern North Sea. Tectonics, 20/4, 585-599.

Price, S., Brodie, J., Whitham, A. \& Kent, R. 1997. Mid-Tertiary rifting and magmatism in the Traill $\varnothing$ region, East Greenland. Journal of the Geological Society, London, 54, 419-434.

Ranalli, G. 1995. Rheology of the Earth. Chapman and Hall, New York.

Rasmussen, E. S. 2004. The interplay between true eustatic sea-level changes, tectonics, and climate changes: what is the dominating factor in sequence formation of the Upper Oligocene-Miocene succession in the eastern North Sea Basin, Denmark? Global and Planetary Change, 41, 15-30.

Reinecker, J., Heidbach, O., Tingay, M., Sperner, B. \& Müller, B. 2005. The release 2005 of the World Stress Map (available online at www. world-stress-map.org).

Ren, S., Skogseid, J. \& Eldholm, O. 1998. Late Cretaceous-Paleocene extension on the Vøring Volcanic Margin. Marine Geophysical Researches, 20, 343-369.

Riise, L., Ottesen, D., Berg, K. \& Lundin, E. 2005. Large-scale development of the mid-Norwegian margin during the last 3 million years. Marine and Petroleum Geology, 22, 33-44.

RitZManN, O. \& JOKAT, W. 2003. Crustal structure of northwestern Svalbard and the adjacent Yermak Plateau: evidence for Oligocene detachment tectonics and non-volcanic breakup. Geophysical Journal International, 152, 139-159.

Roberts, A. M., Corfield, R., Matthews, S., KuszNiR, N. J. \& Hooper, R. 2002. Mapping Palaeostructure and palaeobathymetry along the Norwegian continental margin. Frontier Exploration of Volcanic Continental Margins, Geological Society, London, 17-18 September 2002.

Roberts, D. G. 1989. Basin inversion around the British Isles. In: CoOper, M. A. \& Williams, D. G. (eds) Inversion Tectonics. Geological Society, London, Special Publications, 44, 131-150.

Rumph, B., Reaves, C. M., Orange, V. G. \& RobinSON, D. 1993. Structuring and transfer zones in the Faroe Basin in a regional tectonic context. In: PArker, J. R. (ed.) Petroleum Geology of Northwest Europe. Proceedings of the 4th Conference. Geological Society, London, 999-1010.

SMallwood, J. R. 2004. Tertiary inversion in the FaroeShetland Channel and the development of major erosional scarps. In: DAvies, R. J., Stewart, S. A., CARTWight, J. A., LAPPin, M. \& UNDERhiLl, J. R. (eds) 3D seismic technology: application to the exploration of sedimentary basins. Geological Society London, Memoir 29, 187-198.

SRivastava, S. P. \& Roest, W. R. 1999. Extent of oceanic crust in the Labrador Sea. Marine and Petroleum Geology, 16, 65-84.

Steel, R., GJeldberg, J., Nøttvedt, A., HellandHansen, W., Kleinspehn, K. \& RYe-Larsen, M. 1985. The Tertiary strike-slip basins and orogenic belt of Spitsbergen. Society of Economic Palaeotonologsists and Mineralogists, Special Publication 37, 339-360. 
Stuevold, L. M., Skogseid, J. \& Eldholm, O. 1992. Post-Cretaceous uplift events on the Voring continental margin. Geology, 10, 919-922.

Stoker, M. S., Praeg, D., Shannon, P. M., Huelstuen, B. O., Laberg, J. S., Nielsen, T., van Weering, T. C. E., Sejrup, H. P. \& Evans, D. 2005a. Neogene evolution of the Atlantic continental margin of NW Europe (Lofoten Islands to SW Ireland): Anything but passive. In: DorÉ, A. G. \& Vining, B. A. (eds) Petroleum Geology: North-West Europe and Global Perspectives. Proceedings of the 6th Petroleum Geology Conference. Geological Society, London, 1057-1074.

Stoker, M. S., Hoult, R. J., Nielsen, T., HJelstuen, B. O., Laberg, J. S., Shannon, P. M., Praeg, D. Mathiesen, A., VAn Weering, T. C. E. \& MCDonnell, A. 2005b. Sedimentary and oceanic response to early Neogene compression on the NW European margin. Marine and Petroleum Geology, 22, $1031-1044$.

Talwani, M. \& Eldholm, O. 1977. Evolution of the Norwegian-Greenland Sea. Geological Society of America Bulletin, 88, 969-999.

Torsvik, T. H., Mosar, J. \& Eide, E. A. 2001. Cretaceous-Tertiary geodynamics: A North Atlantic exercise. Geophysical Journal International, 146, $850-866$.

Torsvik, T. M., Smethurst, M. A., Redfield, T. F., Gaina, C., Steinberger, B., Rousse, S., Buiter, S., Müller, R. D. \& Gurnis, M. 2006. "Splates: Paleogeographic reconstruction software", Norwegian Geological Survey, report 2006.060.

Tsikalas, F., Faleide, J. I., Eldholm, O. \& Wilson, J. 2005. Late Mesozoic-Cenozoic structural and stratigraphic correlations between the conjugate mid-Norway and NE Greenland continental margins. In: DORÉ, A. G. \& VINING, B. A. (eds)
Petroleum Geology: North-West Europe and Global Perspectives. Proceedings of the 6th Petroleum Geology Conference. Geological Society, London, 785-802.

Turcotte, D. L. \& Schubert, G. 1982. Geodynamics. John Wiley \& Sons, New York.

VÅgnes, E., GABRIELSEn, R. H. \& HAREMo, P. 1998. Late Cretaceous-Cenozoic intraplate contractional deformation at the Norwegian continental shelf: timing, magnitude and regional implications. Tectonophysics, 300, 29-46.

VendeVille, B. C. \& JACKSON, M. P. A. 1992. The rise of diapirs during thin skinned extension. Marine and Petroleum Geology, 9, 331-353.

Vogt, P. R., Johnson, G. L. \& KRISJANSSON, L. 1980. Morphology and magnetic anomalies north of Iceland. Journal of Geophysics, 47, 67-80.

VorRen, T. O. \& LABERG, J. S. 1997. Trough mouth fans - palaeoclimate and ice-sheet monitors. Quaternary Science Reviews, 16, 865-881.

White, R. S., Spence, G. D., Fowler, S. R., McKenZie, D. P., Westbrook, G. K. \& Bowen, A. N 1987. Magmatism at rifted continental margins. Nature, 330, 439-444.

Withjack, M. O., Meisling, K. E. \& Russell, L. R 1989. Forced folding and basement-detached normal faulting in the Haltenbanken area, offshore Norway. In: TANKARD, A. J. \& BALKWILL, H. R. (eds) Extensional Tectonics and Stratigraphy of the North Atlantic Margins. American Association of Petroleum Geologists Memoir, 46, 567-575.

ZIEGLER, P. A. 1988. Evolution of the Arctic-North Atlantic and the Western Tethys. American Association of Petroleum Geologists Memoir, 43.

ZIEGLER, P. A. 1993. Plate-moving mechanisms: their relative importance. Journal of the Geological Society, London, 150, 927-940. 